\title{
Innovative Regulation of Meat Consumption in South Africa: An Environmental Rights Perspective
}

\section{P.E.R}

Pioneer in peer-reviewed, open access online law publications

Authors

Tokyo Ndlela and Melanie $\mathrm{J}$ Murcott

Affiliation

University of Pretoria

South Africa

Email

tokyo.ndlela@gmail.com melanie.murcott@up.ac.za

Date Submission

24 October 2019

Date Revised

25 February 2021

Date Accepted

25 February 2021

Date published

29 March 2021

Editor Prof Tumi Mmusinyane

How to cite this article

Ndlela TS and Murcott MJ

"Innovative Regulation of Meat Consumption in South Africa: An Environmental Rights Perspective" PER / PELJ 2021(24) - DOI

http://dx.doi.org/10.17159/17273781/2021/v24i0a7519

Copyright

DO

http://dx.doi.org/10.17159/1727-

3781/2021/v24i0a7519

\begin{abstract}
Meat production is a human activity driven by meat consumption, a human behaviour normalised in today's society. Human activity stems from particular psychological patterns (manifesting as human behaviour). It is argued that through regulating the human behaviour of meat consumption the environmentally harmful impacts of the human activity of meat production can potentially be mitigated. In particular, adopting an environmental rights perspective and a social ecological ethic, this article proposes the introduction of a meat tax in South Africa as an innovative means of regulating the human behaviour of meat consumption.

In Section 1 we introduce our arguments and discuss the social, ecological, ethical and environmental rights perspective from which we make them. Next, in Section 2 we discuss some of the most significant environmental harms caused by meat production and thus, indirectly, meat consumption. Then, in Section 3 we critically evaluate the command-and-control regulatory measures that currently regulate the human activity of meat production and seek in no meaningful way to regulate the psychological patterns associated with that human activity, the human behaviour of meat consumption. Lastly, in Section 4 we propose a meat tax, a type of market-based mechanism, as a regulatory measure which we argue could serve to influence human behaviour in order to reduce meat consumption and give better effect to the environmental right.
\end{abstract}

\section{Keywords}

Meat tax; ecologically sustainable development; environmental right; meat production; meat consumption. 


\section{Introduction}

This article proposes the introduction of a meat tax in South Africa as an innovative means of regulating the human behaviour of meat consumption. ${ }^{1}$ A meat tax is not proposed as a panacea for the socio-ecological harms caused by meat production or meat consumption, but is rather intended to help begin a conversation towards regulatory reform in South Africa. ${ }^{2}$ Our focus is on the mass production of meat rather than small-scale production, since as we argue below, the processes involved in mass production are particularly harmful to humans and the environment. ${ }^{3}$ Further, we focus on the regulation of human activity and behaviour. A discussion of animal welfare and animal rights in the context of meat production and consumption falls outside of the scope of this article. ${ }^{4}$

Meat production is a human activity driven by meat consumption, a particular form of human behaviour normalised in today's society. ${ }^{5}$ This

* Tokyo Sulethu Ndlela. LLB (UP) LLM (UP). General Counsel at Finance Hut (Pty) Ltd, South Africa. Email: tokyo.ndlela@gmail.com. https://orcid.org/0000-00023820-600X. This submission is based on the author's LLM dissertation with the same title, submitted to the University of Pretoria in 2019.

** Melanie Jean Murcott. LLB (UCT) LLM (UP) LLD (NWU). Senior Lecturer at the University of Pretoria, Department of Public Law, South Africa. Email: melanie.murcott@up.ac.za.https://orcid.org/0000-0001-8311-2195.

1 As provided for in reg 1 of the Regulations Regarding the Classification and Marketing of Meat Intended for Sale in the Republic of South Africa, 2006 (GN 863 in GG 29155 of 1 September 2006), made in terms of Agricultural Product Standards Act 119 of 1990, for the purposes of this article, "meat" connotes "those parts of a carcass which are normally sold for human consumption."

2 To achieve a sustainable transition to plant-based diets, a meat tax would have to be one of many other regulatory reforms aimed at decreasing the consumption of meat. See Vinnari and Vinnari 2014 J Agric Environ Ethics 383-384 for other possible policy measures.

3 See for example: Anomaly 2015 Public Health Ethics 246-252; Wilson 2019 Forum of Animal Law Studies 46-50. In order to understand what environmental harm is, one must first understand what the "environment" is. In $s$ of the National Environmental Management Act 107 of 1998 (NEMA), the "environment" is defined as: "The surroundings within which humans exist and that are made up of - (i) the land, water and atmosphere of the earth; (ii) micro-organisms, plant and animal life; (iii) any part or combination of (i) and (ii) and the interrelationships among and between them; and (iv) the physical, chemical, aesthetic and cultural properties and conditions of the foregoing that influence human health and well-being".

$4 \quad$ For a discussion on animal rights and welfare in the context of mass meat production see for example: Puryear, Bruers and Erdös 2017 J Agric Environ Ethics 316-322.

$5 \quad$ Vlek and Steg 2007 JSI 3. In Hornby Oxford Advanced Learner's Dictionary 14, "human activity" is defined as "a situation in which something is happening, or a lot of things are being done" by a human(s). In Holdershaw and Gendall "Understanding and Predicting Human Behaviour" 2-3, "human behaviour" is identified as "psychological patterns which respond to internal and external stimuli and can be used as a method to "predict and understand human action". Thus, human behaviour provides a psychological understanding for human activity. In Vandrovcova 
article argues that a shift in focus to the regulation of the human behaviour of meat consumption could serve to mitigate at least some of the harms caused by the human activity of meat production, the latter being the current focus of existing regulatory measures. ${ }^{6}$ Human activity stems from particular psychological patterns (manifesting as human behaviour). ${ }^{7}$ We argue that by interrogating and better regulating these psychological patterns, the harmful effects of meat production could potentially be mitigated. ${ }^{8}$ Human behaviour is responsible for the progression of many environmental harms, ${ }^{9}$ including climate change, which has been proven to be a colossal threat to the environment and human survival. ${ }^{10}$ Moreover, there is a great deal of scientific research evidencing that globally, meat production is a significant contributor to socio-ecological harms, especially climate change. ${ }^{11}$ For instance, it is reported that globally meat production contributes to climate change to a greater degree than the transport industry. ${ }^{12}$ Some of the most significant socio-ecological harms caused by meat production in order to enable mass meat consumption are discussed in Section 2.

In Section 3 we explain that under South African law the socio-ecological impacts of meat production are intended to be regulated primarily by command-and-control measures. These are regulatory measures that "involve setting standards to protect or improve environmental quality" and

"Psychology of Meat Consumption" 7-9, the author argues that habit leads to behaviour formation (patterns), in terms of the theory of "planned behaviour", and thus the consumption of meat is a behaviour fuelled by various factors such as social norms.

$6 \quad$ The regulation of human behaviour through market-based mechanisms such as taxation (as will be argued below) forms part of the concept of "behavioural economics". In Miller, Amit and Posten "Behavioral Economics" 1, behavioural economics "explores what affects people's economic decisions and the consequences of those decisions for market prices, returns, and resource allocation."

$7 \quad$ Kurz et al 2015 Wiley Interdiscip Rev Clim Change 114-115.

$8 \quad$ Kurz et al 2015 Wiley Interdiscip Rev Clim Change 113-114; Happer and Wellesley 2019 Food Security 125.

$9 \quad$ Vlek and Steg 2007 JSI 1-2. In Vumbhoni Critical Analysis of the Law on Duty of Care to the Environment 15, an "environmental harm" is defined as: "any adverse effect, or potential adverse effect (whether temporary or permanent and of whatever magnitude, duration or frequency) on an environmental value, and includes environmental nuisance"; IPCC Global Warming of $1.5^{\circ} \mathrm{C} 362$.

10 See for example UN High Commissioner for Human Rights 2019 https://www.ohchr.org/EN/NewsEvents/Pages/DisplayNews.aspx?NewsID=24735\& LangID=E; Kotzé 2014 JERL 128-131.

11 Poore and Nemecek 2019 Science 360 1-2; Petrovic et al 2015 Procedia Food Science 235-237; FAO State of Food and Agriculture 53-71; Tuomisto and Teixeira de Mattos 2011 Environ Sci Technol 6117-6123.

12 Bailey, Froggatt and Wellesley Livestock 2; FAO State of Food and Agriculture 64. 
imposing a consequence for failure to comply. ${ }^{13}$ We show that in the context of the meat industry, command-and-control measures focus on the regulation of the human activity of meat production (in the form of a "listed activity") rather than the psychological patterns associated with that human activity (the human behaviour of meat consumption). ${ }^{14}$ We argue that command-and-control measures are insufficient to ensure that the environment is protected in a manner that secures ecological sustainability. Accordingly, it is argued that these measures cannot fully give effect to the environmental right provided for in section 24 of the Constitution of the Republic of South Africa, 1996. ${ }^{15}$ The environmental right provides that the environment is to be protected for the benefit of present and future generations "through reasonable legislative and other measures that secure ecologically sustainable development ... while promoting justifiable economic and social development." 16 The entrenchment of this right entails that all legislation and methods of regulation ought to "ensure that development is compatible with the need to protect and improve the environment."17

In Section 4 this article proposes an alternative to imposing merely command-and-control measures by motivating for the introduction of a meat tax, a market-based mechanism which could serve to influence human

$13 \quad$ Elazegui 2002 Policy Brief 1.

14 Junquera and Del Brio 2016 Sustainability 1; Feris 2006 PELJ 1; Wilson 2005 Fordham Envtl L Rev 224; Zhang 2013 CJPRE 87-88. The human activity of meat production is a listed activity in terms of ss 24(2) and 24D of NEMA and can be found in Environmental Impact Assessment Regulations Listing Notice 1, 2014 (GN R983 in GG 38282 of 4 December 2014) (Listing Notice 1). Several activities related to factory farming are also listed as activities 4, 5, 31 and 32.

15 Section 24 of the Constitution of the Republic of South Africa, 1996 (the Constitution) provides that: "Everyone has the right to - (a) an environment that is not harmful to their health or well-being; and (b) to have the environment protected, for the benefit of present and future generations, through reasonable legislative and other measures that - (i) prevent pollution; (ii) promote conservation; and (iii) secure ecologically sustainable development and use of natural resources while promoting justifiable economic and social development." It is of considerable importance that all forms of regulation give effect to the Constitution, as it is the supreme law in South Africa (in terms of $s 2$ of the Constitution).

16 Section 24(b)(iii) of the Constitution.

17 Fuel Retailers Association of Southern Africa v Director General: Environmental Management, Department of Agriculture, Conservation and Environment, Mpumalanga Province 20076 SA 4 (CC) para 46. 
behaviour in order to reduce meat consumption and give better effect to the environmental right. ${ }^{18}$ Market-based mechanisms are defined as: ${ }^{19}$

regulations that encourage behaviour through market signals rather than through explicit directives regarding pollution control levels or methods.

This article proposes the introduction of a meat tax from an environmental rights perspective that adopts a social ecological ethic. ${ }^{20} \mathrm{~A}$ social ecological ethic sees the environment and humans as "strongly coupled to the point that they should be perceived as one social ecological system." ${ }^{21}$ Further, a social ecological ethic recognises "ecological limits as connected to limits to human flourishing".22 This ethic differs from an anthropocentric ethic that views the environment as valuable only to the extent that it furthers human interests. ${ }^{23}$ Rejecting binary thinking towards the normative value placed on the environment, we view human and non-human life as intertwined and interdependent, adopting the point of departure that humans exist in complex social ecological systems, and that the ecological system is "the most encompassing system" known to humans, in that it is the foundation for the existence of all other systems (including socio-economic systems). ${ }^{24}$ Current patterns of meat consumption disregard ecological limits, however, as excessive meat consumption takes place largely in the form of human indulgence to the detriment of the ecology and the well-being of people. ${ }^{25}$

The environmental rights perspective adopted in this article focusses on securing "ecologically sustainable development" as provided for in section

18 Springmann et al 2018 PLOS ONE 6.

19 Stavins Market-based Environmental Policies 1. As with the command-and-control approach, the concept of market-based mechanisms also plays a large role in this article and will be expounded upon in section 4.

In Zimmerman and Cliffs $2001 \mathrm{http}: / /$ dwardmac.pitzer.edu/Anarchist Archives/bookchin/coceol.html, "social ecology" is described as "the recognition of the often-overlooked fact that nearly all our present ecological problems arise from deep-seated social problems." Stockholm Resilience Centre 2015 https://www.stockholmresilience.org/ research/research-news/2015-02-19-what-is-resilience.html.

$22 \quad$ Murcott "Introducing Transformative Constitutionalism" 292.

23 Washington et al 2017 Ecological Citizen Y. A critique of the anthropocentric ethic is that it subordinates non-human life to human life, and countenances the exploitation of non-human life to the extent that such exploitation furthers human interests. In the context of the regulation of meat production and consumption such an ethic permits excessive meat production and consumption, despite the harm this activity and behaviour causes to humans and the environment.

24 Bosselmann "Ever-increasing Importance of Ecological Integrity" 225.

25 De Baker and Dagevos 2012 J Agric Environ Ethics 881; Anomaly 2015 Public Health Ethics 251. Wilson 2019 Forum of Animal Law Studies 46-50. We deliberately use the word "indulgence" because the quantity of meat consumed by people who purchase factory farmed meat is well beyond what is necessary for survival. 
24 of the Constitution. ${ }^{26}$ In order to protect the environment, section 24 of the Constitution envisages that reasonable legislative and other measures be put in place to secure ecologically sustainable development, whilst promoting only justifiable social and economic development. There is limited scholarship on or judicial engagement with the significance of the Constitution's emphasis on ecological sustainability. ${ }^{27}$ Feris $^{28}$ argues that ecologically sustainable development entails a "type of sustainable development" that "places emphasis on environmental considerations and as such places the environmental value centre-stage." We agree, but also submit that ecological sustainability connotes "using, conserving and enhancing the community's resources so that ecological processes, on which life depends, are maintained, and the total quality of life, now and in the future, can be increased."29 From this point of departure, ecologically sustainable development entails the systematic acknowledgement of environmental concerns "conceptualised as a set of interconnected ecological pressures that require a similarly interconnected economic, social and political response."30 Further, development that sustains the ecology calls on people in South Africa to view themselves not only as consumers of the environment but also as custodians thereof. ${ }^{31}$ In light of these interconnected environmental concerns, Kotzé32 argues for law and policy reform that brings forth a "new understanding of the humanenvironment interface".

A new understanding of the role of law in responding to socio-ecological harms is beginning to emerge in South Africa. For instance, in what is widely regarded as South Africa's first climate change case ${ }^{33}$ the High Court held that in order to pursue sustainable development and intergenerational justice as required by the environmental right, a climate change impact assessment had to be conducted and taken into account before officials

26 The concept of "ecologically sustainable development" is mentioned in s 24(b)(iii) of the Constitution.

27 Feris 2008 CCR 252 briefly engages with the idea. Also see Murcott "Introducing Transformative Environmental Constitutionalism" 291-292.

28 Feris 2008 CCR 252.

29 Drawing on the Australian experience as discussed in Curran and Hollander 2015 Australas J Environ Manag 3. Also see Kotzé 2014 JERL 150-154.

30 Curran and Hollander 2015 Australas J Environ Manag 3. Also see Murcott "Introducing Transformative Constitutionalism" 292.

Murcott 2015 SALJ 903-904.

Kotzé 2014 JERL 137.

See for instance Ashukem 2017 LEAD Journal 37-43; Peel and Osofsky 2018 TEL 59-60; Humby 2018 JEL 146-154. 
could lawfully approve the construction of a coal-fired power plant. ${ }^{34}$ This article explores a proposed meat tax as a measure aimed at securing ecologically sustainable development in pursuit of the environmental right in view of the significant influence that tax can have in the social, political and economic realm. ${ }^{35}$

\section{Socio-ecological harms associated with meat production}

In this section we describe some of the major socio-ecological harms caused by meat production as well as some of the ways in which meat consumption propels meat production, and thus the harms caused thereby. ${ }^{36}$ We do so to argue for a shift in regulation from a focus on purely command-and-control measures over environmental harms caused by meat production to the incorporation of a possible market-based mechanism focussed on meat consumption.

The activities that take place to mass produce meat are conducted primarily by commercial producers/farmers, auctions and marketing agents, feedlots/factory farms, abattoirs, wholesalers, and retailers. ${ }^{37}$ Factory farms and abattoirs generate the greatest amount of greenhouse gas emissions within the production chain, and thus form the focus of this article, when discussing meat production. ${ }^{38}$ We illustrate that meat production in factory

Earthlife Africa Johannesburg v Minister of Environmental Affairs [2017] 2 All SA 519 (GP) paras 82-83. Khan 2015 Laws 638-639. Other possible measures are discussed in Vinnari and Vinnari 2014 J Agric Environ Ethics 383-390.

For reasons of scope and length, we focus on the relationship between meat production and climate change, as well as the relationships amongst meat production and water security and land degradation and other forms of pollution. Another particularly relevant socio-ecological harm is the spread of disease from animals to humans (zoonosis), as discussed in Anomaly 2015 Public Health Ethics. For various other socio-ecological harms arising from meat production and the need for "sustainable diets" see Fresán and Sabaté 2019 Advances in Nutrition S380S382.

Labuschagne, Louw and Ndanga "Consumer-orientated Study of the South African Beef Value Chain" 7-8.

38 Grobler Regulating the Environmental Impacts of Factory Farming 2. According to $\mathrm{s}$ 1 (b) of the Health Act 63 of 1977 (the Health Act), a factory farm - also known as a concentrated animal feeding operation (CAFO or factory farm) - is defined as an "intensive animal feeding system means any farming system having as its objective the breeding of animals or the production of meat, milk, eggs, fur or any other product of animal origin and where the animal in question is kept in a confined space so as to accomplish intensive feeding or maximum control of or maximum food conversion in the animal." According to s 1 of the Meat Safety Act 40 of 2000 (the Meat Safety Act), an abattoir is defined as a "slaughter facility in respect of which a registration certificate has been issued." According to Njisane and Muchenje 2017 AJAS 755756 , factory farms and abattoirs are normally on the same premises, in order to 
farms contributes to climate change, a critical global socio-ecological problem which, as a more immediate, local concern, is exacerbating South Africa's water crisis and contributing to land degradation and air, waste and water pollution.

\subsection{Climate change}

Greenhouse gas emissions are the major cause of climate change, ${ }^{39}$ which has been identified as a global threat, and has led numerous countries to enter into treaties and discussions relating to the mitigation of the effects thereof. ${ }^{40}$ The South African government's National Climate Change Response White Paper, 2011 sets out the country's policy in response to climate change and correctly acknowledges human activity as the primary driver of climate change. However, it would be more precise to acknowledge and engage with the fact that human activity is driven by human behaviour (including consumer behaviour), as human behaviour underlies and drives human activity. ${ }^{41}$ To some extent the White Paper does so. The White Paper states that realising South Africa's commitment to respond to climate change "ultimately will depend on decisions by individual citizens to embrace climate-friendly lifestyles and habits."42 A plethora of scientific research, including that conducted under the aegis of the Intergovernmental Panel on Climate Change (IPCC) - a unique body that draws on the work

maximise food conversion in the animal, and abattoirs are considered part of the factory farm process.

39 National Climate Change Response White Paper, 2011 (GN 757 in GG 34695 of 19 October 2011) (White Paper). According to the White Paper 8 , climate change is "an ongoing trend of changes in the earth's general weather conditions as a result of an average rise in the temperature of the earth's surface often referred to as global warming. The rise in the average global temperature is due, primarily, to the increased concentration of gases known as greenhouse gases in the atmosphere that are emitted by human activities. These gases [primarily carbon dioxide, nitrous oxide and methane] intensify a natural phenomenon called the 'greenhouse effect' by forming an insulating layer in the atmosphere that reduces the amount of the sun's heat that radiates back into space and therefore has the effect of making the earth warmer."

40 According to UN Date Unknown www.un.org/en/sections/issues-depth/climatechange/ 197 countries have ratified the United Nations Framework Convention on Climate Change (1992), 192 parties have signed the Kyoto Protocol to the United Nations Framework Convention on Climate Change (1998), and 175 countries have signed the Paris Agreement (2015).

41 In Swim, Clayton and Howard 2011 Am Psychol 255; Liverani Climate Change and Individual Behavior 2. In Sahney Date Unknown http://www.nptel.ac.in/ courses/110105029/pdf\%20sahany/Module-1-1.pdf, consumer behaviour is defined as "the interplay of forces that takes place during a consumption process, within a consumers' self and his environment" and which further explains "the reasons and logic that underlie purchasing decisions and consumption patterns." White Paper 49. 
of more than one thousand scientists to examine the causes and impacts of climate change - has confirmed this view. ${ }^{43}$

The IPCC has further provided strong evidence that "changes in climate have caused impacts on natural and human systems on all continents and across the oceans." ${ }^{4}$ A major rise in sea level, ocean acidification, changes in average rainfall patterns, increased flooding and droughts have been identified as some of the impacts of climate change, which also seeps into different aspects of existence and negatively affects "lives, livelihood, health, ecosystems, economies, societies, cultures, services, and infrastructures." 45

The human activity of meat production, driven by meat consumption, significantly contributes to climate change, and its dire socio-ecological consequences. Research by, amongst others, the Food and Agriculture Organisation of the United Nations (FAO), which comprises the world's leading researchers and scientists in agricultural matters, indicates that the production of meat contributes about $14.5 \%$ to $51 \%$ of global greenhouse gas emissions, thus being a primary driver of climate change. ${ }^{46}$ In contrast, the transport industry contributes about $14 \%$ of global greenhouse gas emission, and thus arguably has a lesser impact on climate change than the meat production industry. 47 Yet in climate change discourse, whilst reform of the transport industry is typically explicitly addressed, little regard is

43 Chang et al 2018 Hydrol Earth Syst Sci 4794; OCE 2018 https://www.ipcc.ch/site/assets/uploads/sites/2/2019/03/ST1.5_final_310119.pdf 19.

$44 \quad$ IPCC Climate Change 20144.

$45 \quad$ IPCC Climate Change 20145.

46 Goodland and Anhang 2009 https://awellfedworld.org/wpcontent/uploads/Livestock-Climate-Change-Anhang-Goodland.pdf 11; FAO 2017 http://www.fao.org/3/l8098EN/i8098en.pdf 1. In FAO Tackling Climate Change through Livestock xii, a breakdown of the contributors to greenhouse gas emissions in the meat production sector has been provided as follows: "beef and cattle milk production account for the majority of emissions, respectively contributing 41 and 20 percent of the sector's emissions. Pork and poultry and eggs contribute respectively 9 percent and 8 percent of to the sector's emissions; feed production and processing, and enteric fermentation from ruminants are the two main sources of emissions, representing 45 and 39 percent of sector emissions; manure storage and processing represent 10 percent; the expansion of pasture and feed crops into forests account for about 9 percent of the sector's emissions; the consumption of fossil fuel along the sector supply chains accounts for about 20 percent of sector emissions"; FAIRR 2016

https://cdn.fairr.org/2019/01/09115647/FAIRR_Report_Factory_Farming_Assessin g_Investment_Risks.pdf 3 ; $\quad$ IPCC $2018 \quad \mathrm{https} / / / \mathrm{www}$. ipcc.ch/site/assets/ uploads/2019/08/2f.-Chapter-5_FINAL.pdf 62. 
shown to the need to reduce meat consumption and transform meat production practices. ${ }^{48}$

\subsection{Other socio-ecological harms}

As human populations continue to grow and develop neo-liberal capitalist economies that adopt an anthropocentric ethic towards the exploitation of the environment, meat consumption is intensifying, and meat production technology is expanding. ${ }^{49}$ In South Africa the overall estimated population growth rate increased from approximately $1.04 \%$ for the period of 2002 to 2003 to $1.55 \%$ for the period of 2017 to $2018 .^{50}$ Factory farming is a consequence of the need to supply a seemingly ever-growing demand for meat by an expanding population, and accounts for the majority of meat production in South Africa. ${ }^{51}$ Furthermore, approximately $80 \%$ of South Africa's land is used for agricultural purposes and "69\% thereof is used for grazing, which puts significant pressure on agricultural resources". ${ }^{52}$ The reality of South Africa's agricultural landscape is that approximately $60 \%$ of national water is used for watering crops. ${ }^{53}$ The majority of those crops are then fed to animals intended for human consumption. ${ }^{54}$ In this way agriculture for meat production and meat consumption is exacerbating

48 For instance, whilst the White Paper 31-32 includes a flagship programme related to transport to "enhance public transport" and "promote lower-carbon mobility", the need to reform the agricultural sector is addressed only in general terms (White Paper 20-21), with no specific mention of the need to reform the meat industry or reduce meat consumption in particular.

$49 \quad$ Vlek and Steg 2007 JSI 3.

50 Statistics South Africa Mid-year Population Estimates 9.

51 Meissner, Scholtz and Engelbrecht 2013 S Afr J Anim Sci 283. In Worldwatch Institute $2017 \mathrm{http}: / / \mathrm{www}$.worldwatch.org/node/5443, factory farming accounts for the majority of meat production worldwide. Thus, showing that factory farming accounting for the majority of meat production is not only a South African occurrence, but rather a world-wide phenomenon. Grobler Regulating the Environmental Impacts of Factory Farming 13.

Department of Water and Sanitation Date Unknown https://www.dws.gov.za/ IO/Docs/CMA/CMA\%20GB\%20Training\%20Manuals/gbtrainingmanualchapter1.pd; Colvin et al Water 53.

Goldblatt 2010 http://awsassets.wwf.org.za/downloads/facts_brochure_mockup_04 b.pdf 3 and 9, shows that most crops worldwide are fed to animals, thus illustrating that this is not only a South African but a worldwide methodology; Department of Agriculture, Forestry and Fisheries 2017 http://webapps.daff.gov.za/ AmisAdmin/upload/South\%20African\%20Animal\%20Feeds\%20Market\%20Analysi s\%20Report\%202017. pdf 2 reveals South Africa to be the largest African contributor of animal feed to the world, thus emphasising the extent to which South Africa's crops are fed to animals intended for human consumption as meat. 
South Africa's water crisis, which is characterised by periodic droughts which are a consequence of climate change. ${ }^{55}$

In addition to South Africa's water crisis, environmental harms from factory farming that also drive climate change ${ }^{56}$ include land degradation, ${ }^{57}$ air pollution, ${ }^{58}$ waste pollution ${ }^{59}$ and water pollution. ${ }^{60}$ These are discussed next. Whilst we also acknowledge the harm to and exploitation of animals as a deeply problematic aspect of meat production and meat consumption, a discussion of that harm falls outside of the scope of this article. ${ }^{61}$

55 Van Dam 2017 http://edition.cnn.com/2017/05/31/africa/cape-town-drought/ index.html.

56 According to Grobler Regulating the Environmental Impacts of Factory Farming 7-8, "ammonia emissions released from livestock manure may contribute to global warming and acidification; surface run-off and groundwater pollution caused by overapplication of fertilisers, pesticides and slurry; overgrazing and changes in land utilisation, leading to soil and bank erosion as well as siltation of rivers; and drainage of wetlands and the extension of field margins to river banks may lead to loss of habitats and biodiversity."

57 In terms of art $1(\mathfrak{f})$ of the United Nations Convention to Combat Desertification (1994), "land degradation" is defined as a: "reduction or loss, in arid, semi-arid and dry sub-humid areas, of the biological or economic productivity and complexity of rainfed cropland, irrigated cropland, or range, pasture, forest and woodlands resulting from land uses or from a process or combination of processes arising from human activities and habitation patterns, such as: 'soil erosion caused by wind and/or water; deterioration of the physical, chemical and biological or economic properties of soil; and long-term loss of natural vegetation'." In terms of $\mathrm{s} 1$ of the National Environmental Management: Air Quality Act 39 of 2004 (NEMAQA), "air pollution" is defined as "any change in the composition of the air caused by smoke, soot, dust (including fly ash), cinders, solid particles of any kind, gases, fumes, aerosols and odorous substances". In terms of $s$ of the National Environmental Management: Waste Act 59 of 2008 (NEMWA), "waste pollution" is a form of hazardous waste, which is defined as "any waste that contains organic or inorganic elements or compounds that may, owing to the inherent physical, chemical or toxicological characteristics of that waste, have a detrimental impact on health and the environment."

60 In terms of s 1 of the National Water Act 36 of 1998 (NWA), "water pollution" is defined as "the direct or indirect alteration of the physical, chemical or biological properties of a water resource so as to make it $-a$ ) less fit for any beneficial purpose for which it may reasonably be expected to be used; or b) harmful or potentially harmful - aa) to the welfare, health or safety of human beings; bb) to any aquatic or non-aquatic organisms; cc) to the resource quality; or dd) to property."

61 See Puryear, Bruers and Erdös 2017 J Agric Environ Ethics 316-322; Wilson 2019 Forum of Animal Law Studies 48-49. We further support the views expressed in Bilchitz 2012 SAPL 3 with regard to the need to recognise animal rights. However, this article adopts a pragmatic rather than an ethical or philosophical stance towards the human activity of meat production and the human behaviour of meat consumption as a small step towards ecologically sustainable development. 
About 14 million cattle are produced in factory farms in South Africa at any given time. ${ }^{62}$ As part of the meat production process, these animals are "kept in restrictive spaces and the animals are bred and slaughtered on the same premises in order to limit expenses and expedite production."63 Due to the numerous animals produced on factory farms, overgrazing often occurs, which results in desertification and other forms of land degradation. ${ }^{64}$ Research indicates that desertification takes place in arid, semi-arid and dry, sub-humid areas. ${ }^{65}$ South Africa is a semi-arid country and is thus prone to desertification. ${ }^{66}$ The inevitable methane (28 times more potent than carbon dioxide) emitted by the belching of cattle contributes about $39 \%$ to global greenhouse gas emissions by the meat production industry, which results in air pollution. ${ }^{67}$ The typical waste from the slaughter of the animals includes "urine, faeces, discarded milk, blood, detergent, disinfectant, and other waste" and results in waste pollution. ${ }^{68}$ The waste leads to extensive damage to the environment, such as the "reduction of long-term soil fertility, soil erosion, pollution of water supplies, degradation of fragile ecosystems and air pollution caused by methane emissions." ${ }^{69}$ In addition, waste water (filled with high levels of nitrogen and phosphor) can negatively affect the quality of surrounding groundwater and may lead to "severe degradation of aquatic and wetland ecosystems", causing water pollution. ${ }^{70}$

Even the most effective and rigorous regulation of meat production cannot prevent certain harms, which are an inevitable consequence of meat production. These harms include air pollution caused by the belching of cattle and the repercussions surrounding waste pollution. ${ }^{71}$ With an increase in the demand for meat consumption, the "number of animals bred and slaughtered annually will increase" and as a result animal waste, methane emissions, and the space needed to host animals will also

62 Cornelius 2017 http://www.redmeatsa.co.za/wp-content/uploads/2017/03/AMTBeef-Outlook-February-2017.pdf 2. Also see Goldblatt 2010 http://awsassets.wwf.org.za/downloads/facts_brochure_mockup_04_b.pdf 3 in FAO 2018 http://www.fao.org/3/i8384en/l8384EN.pdf 8.

$63 \quad$ Grobler Regulating the Environmental Impacts of Factory Farming 1.

64 Grobler Regulating the Environmental Impacts of Factory Farming 11.

65 Briassoulis 2018 Land 3.

66 Botai, Botai and Adeola 2018 S Afr J Sci 70, 77.

67 Grossi et al 2019 Animal Frontiers 69.

Grobler Regulating the Environmental Impacts of Factory Farming 1-2.

Grobler Regulating the Environmental Impacts of Factory Farming 2; Turner Factory Farming and the Environment 27.

$70 \quad$ Grobler Regulating the Environmental Impacts of Factory Farming 8.

71 Grossi et al 2019 Animal Frontiers 69; Turner Factory Farming and the Environment 27. 
increase. ${ }^{72}$ Thus, the land degradation, air pollution, waste pollution and water pollution caused by meat production will be compounded, with devastating socio-ecological consequences, particularly given the spectre of climate change.

\subsection{The correlation between meat consumption and meat production}

South Africa consumes approximately 2.9 million tons of beef, pork and poultry per annum. ${ }^{73}$ According to the Bureau for Food and Agriculture, there will be a $38 \%$ increase in poultry consumption in the next decade, as well as a $28 \%$ increase in beef consumption and a $33 \%$ increase in pork consumption. ${ }^{74}$ In light of these projections, it was recommended that there should be an increase in the importation of meat products, as the current rate of meat production in South Africa is considered incapable of satiating the high level of meat consumption (despite the increase in the use of commercial farming methods). ${ }^{75}$ The high levels of meat consumption are further illustrated by the fact that South Africans consume between 60 to 70 kilograms of meat per person per year, the highest rate of meat consumption in Africa. ${ }^{76}$ Furthermore, South Africa has been globally ranked $8^{\text {th }}$ in terms of the highest level of poultry consumption per capita and $16^{\text {th }}$ with regard to beef consumption per capita. ${ }^{77}$ Meat production is necessarily propelled by this high level of meat consumption. ${ }^{78}$ Yet an increase in meat production will give rise to a concomitant increase in the socio-ecological harms indicated above.

\section{The threat of meat production under a command-and- control regulatory method}

Under South African environmental law, the socio-ecological harms caused by the human activity of meat production are primarily regulated through

72 Grobler Regulating the Environmental Impacts of Factory Farming 2.

73 United States Department of Agriculture, Foreign Agricultural Service 2015 https://www.fas.usda.gov/data/south-africa-south-african-meat-market 4.

74 United States Department of Agriculture, Foreign Agricultural Service 2015 https://www.fas.usda.gov/data/south-africa-south-african-meat-market 4.

75 United States Department of Agriculture, Foreign Agricultural Service 2015 https://www.fas.usda.gov/data/south-africa-south-african-meat-market 4.

76 Ritchie and Roser 2017 https://ourworldindata.org/meat-and-seafood-productionconsumption.

77 Gous 2018 https://www.timeslive.co.za/news/south-africa/2018-12-10-southafricans-love-meat-but-how-do-we-stack-up-globally/.

78 Ritchie and Roser 2017 https://ourworldindata.org/meat-and-seafood-productionconsumption. 
command-and-control measures. ${ }^{79}$ In order to explain the links between command-and-control measures and the harms caused by meat production, this section provides an overview of this regulatory method and its shortcomings. This section describes the command-and-control regulatory method in more detail, and argues that it does not adequately give effect to the environmental right in the context of regulating meat production.

\subsection{An overview of the command-and-control regulatory method}

Command-and-control measures ${ }^{80}$ operate in various areas of the South African meat production industry, which is regulated by, among others, the Constitution, NEMA, the National Environmental Management: Waste Act (NEMWA), the National Environmental Management: Air Quality Act (NEMAQA), the Health Act, and the Conservation of Agricultural Resources Act. ${ }^{81}$ The command-and-control measures for environmental enforcement involve direct regulation in terms of which polluters are required by law to take certain measures and actions to mitigate the effects of the harms they cause. ${ }^{82}$ These measures are two-fold, as they establish particular legal standards or threshold requirements (which form the command aspects of such measures), and then allow for the enforcement of compliance through the use of certain enforcement mechanisms (which form the control aspects of such measures) ${ }^{83}$

The command aspect of command-and-control measures is typically implemented in the first instance through administrative measures. ${ }^{84}$ These have the underlying aim of empowering officials to grant permission or authorisation to conduct regulated activities and to direct polluters and other environmental offenders to comply with the law(s) they have contravened and to remedy any harm they may have indirectly or directly caused to the environment. ${ }^{85}$ Compliance notices, directives, abatement notices, and the withdrawal of authorisation to conduct a listed activity are examples of

79 Junquera and Del Brio 2016 Sustainability 1; Feris 2006 PELJ 1. The human activity of meat production is a listed activity in terms of Ss 24(2) and 24D of NEMA and regulated under Listing Notice 1 (see activities 4, 5, 31 and 32, for instance). See Craigie, Snijman and Fourie "Dissecting Environmental Compliance" 52, 56 and 57.

Conservation of Agricultural Resources Act 43 of 1983.

Khan Academy Date Unknown https://www.khanacademy.org/eceonomicsfinancedomain/microeconomics/consumer-producer-

surplus/environmentalregulation/a/command-and-control-regulation-cnx.

Feris 2006 PELJ 1-2.

Winstanley "Administrative Measures" 225.

Winstanley "Administrative Measures" 225. 
administrative measures. ${ }^{86}$ In addition, licence or permit systems form part of administrative measures (which "constitute the prime regulatory technique as far as environmental conservation and pollution control are concerned"). ${ }^{87} \mathrm{~A}$ licence or permit system involves the issuing of licences or permits and criminal sanctions for failure to comply with the requirements thereof. ${ }^{88}$ An example of a licence system can be found in Chapter 4 of the National Water Act (the NWA), which empowers an official to grant a water use licence for certain water uses, and also empowers officials to issue compliance notices if the water user fails to act in accordance with the licence.

When there is non-compliance with a command, then the control aspect of a command-and-control measure is executed through criminal measures or civil measures. Criminal measures entail the application of criminal law in ensuring environmental compliance (normally manifesting in the form of a fine or incarceration). ${ }^{89}$ For instance, in section 151(1)(a) of NWA, a command is established, as it provides that no person may use water otherwise than as permitted under NWA. Section 151(2) of NWA constitutes the control, as it states that any person who contravenes any provision of subsection (1) is guilty of an offence and is liable to a fine or imprisonment. Civil measures are based on the common law (which refers to English and Roman-Dutch custom as it has evolved on a case-by-case basis through judicial precedent), and have been codified in statutes to some degree..$^{90}$ Common law remedies consist of abatement orders, interdicts, compensation for damages and judicial review. ${ }^{91}$ Following the above example, section 155 of NWA embodies a civil measure, as it states that a High Court may grant an interdict or any other appropriate order against any person who has contravened any provision of NWA. Next, we discuss some of the main command-and-control measures that regulate the meat production process.

\subsubsection{Application of command-and-control measures in the setting of meat production}

Before constructing a factory farm, an environmental impact assessment must be conducted for the human activities related to factory farming found

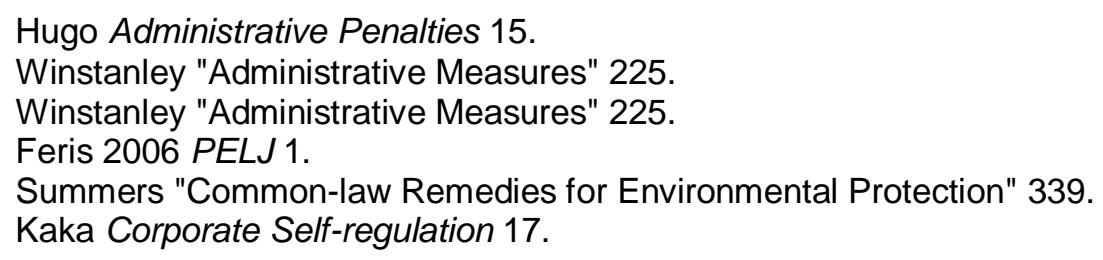


in Listing Notice 1.92 An environmental impact assessment forms part of the requirements for the issuing of an environmental authorisation and numerous other licences and permits under various environmental legislation needed for the operation of a factory farm. ${ }^{93}$ For instance a water use licence is necessary for: the storage of water, the extraction of water from a water resource, the obstruction of the flow of water in a watercourse, and the disposal of waste in a manner which may have a negative impact on a water resource and cause a change in the characteristics of a watercourse. ${ }^{94}$ Furthermore, an atmospheric emission licence is required for manure storage and the processing of animal matter. ${ }^{95}$ The operation of a factory farm also requires a waste management licence for the processing of animal waste and the storage of animal manure. ${ }^{96}$

Failure to obtain the necessary environmental authorisation and the other permits and licences required before the commencement of the operation of a factory farm could result in a fine or imprisonment by virtue of various criminal measures imposed under environmental legislation. ${ }^{97}$

One of the major criticisms of command-and-control measures is that all of the commands prescribed by the relevant laws countenance a considerable degree of harm to the environment (discussed in Section 2), albeit within

92 In terms of reg 1 of the Environmental Impact Assessment Regulations, 2014 (GN R982 in GG 38282 of 4 December 2014) (Environmental Impact Assessment Regulations (2014)) promulgated in terms of NEMA, an "environmental impact assessment" is defined as "a systematic process of identifying, assessing and reporting environmental impacts associated with an activity and includes basic assessment and the scoping and environmental impact reporting process." In Grobler Regulating the Environmental Impacts of Factory Farming 24, the human activities related to factory farming are listed in Listing Notice 1 as follows: activity 4 refers the construction of facilities or buildings used for a high concentration of animals for commercial purposes which exceed certain densities; activity 31 refers to the expansion of facilities or buildings as mentioned in activity 4; activity 5 refers to the construction of facilities or buildings for the concentration of more than 1000 poultry per facility in an urban area and more than 5000 poultry per facility outside urban areas, excluding chicks not exceeding the age of 20 days; activity 32 refers to the expansion of the facilities or buildings as mentioned in activity 5 .

93 Section 24 of NEMA; s 26(o)(ii) of NWA; s 39 of NEMAQA; s 20(a) of NEMWA.

94 Sections 21 and 22 of NWA.

95 Section 21 of NEMAQA. In terms of activity 19 of Listing Notice 1 "animal matter processing" includes tanning, animal slaughter, rendering plants, animal carcasses, waste disposal or recycling.

96 In terms of Schedule 1 of NEMWA, s 10 refers to animal manure at a facility which processes, treats or stores an excess of tonnes of manure on a monthly basis, and $\mathrm{s} 11$ refers to the processing of animal waste at biogas installations where the facility receives five tonnes or more per day, including animal manure, abattoir waste or vegetable waste.

97 Section 49B of NEMA; s 155 of NWEMWA; s 67 of NEMWA; s 51 of NEMAQA. 
prescribed thresholds. ${ }^{98}$ Another criticism is that these measures are reactive in nature, and fail to address the underlying causes of the harmful activity being regulated (meat consumption). ${ }^{99}$ These measures thus offer limited protection to the environment in the context of regulating meat production. Further shortcomings of this method of regulation are discussed next. First, we consider the problematic nature of section 24G of NEMA, which allows for the ex post facto authorisation of certain environmentally harmful human activities that commenced without the applicable license. Second, we discuss some of the limitations of criminal sanctions, a principal control measure in the regulation of meat production. We then evaluate whether command-and-control measures are sufficient to give effect to the environmental right provided for in section 24 of the Constitution.

\subsection{Shortcomings of the command-and-control regulatory method}

Section $24 \mathrm{G}$ of NEMA allows for the authorisation of illegally commenced human activities after the fact. ${ }^{100}$ Section $24 G$ has been criticised as it gives a "green light approval to 'over-hasty developers to undertake activities which may have a substantial detrimental effect on the environment"', and it affords them the possibility of a "quick fix approval" once a development is already complete. ${ }^{101}$ The reactive nature of command-and-control measures, exemplified by section $24 \mathrm{G}$, is one of the numerous shortcomings of this regulatory method, including in the context of meat production, since this provision allows, for instance, the operation of a factory farm to be authorised after its construction with retrospective effect. ${ }^{102}$

98 In Salzman 2013 Duke Envtl L \& Pol'y F 365, it is argued that the command-andcontrol regulatory method does not encourage innovation because once the "regulated party has satisfied the necessary requirement, the law creates no incentive to reduce harmful activities further." Thus, those harmful activities remain legally perpetual.

Also see Johnson 1999 Wash \& Lee L Rev 111, who discusses numerous criticisms against the command-and-control regulatory method in relation to environmental law, such as that command and control measures impose: "unreasonable information-gathering burdens and exorbitant costs on government" and "disproportionate burdens on new pollution sources". The author further points out that this method "provides no incentives to polluters to develop new strategies to reduce their pollution beyond the levels required by law."

100 Not only does s 24G of NEMA promote the continuance of environmental destructive activity, but the same occurs pursuant to s $22 \mathrm{~A}(4)$ of the National Environmental Management Amendment Act 20 of 2014.

101 Kohn 2012 SAJELP 3.

102 Kohn 2012 SAJELP 23. 
Criminal prosecutions for violations of the command measures are lengthy, slow and onerous. ${ }^{103}$ This is because the evidence gathered must be capable of proving the alleged violation beyond a reasonable doubt, a challenging burden to discharge (including in cases about harm caused by methane emissions caused by factory farming and water pollution and land degradation arising from poor waste and water management). ${ }^{104}$ Furthermore, officials are normally unwilling to prosecute offenders for environmental offences, as such offences are not traditionally seen as morally wrong. ${ }^{105}$ An additional weakness of criminal measures is that, due to the complex nature of environmental law, highly skilled and knowledgeable prosecutors are needed to prosecute such cases. ${ }^{106}$ There is an insufficient number of experts in this field and judicial officers are not generally exposed to many environmental law cases. ${ }^{107}$ Civil measures face the same problem, as the judicial officers presiding over these cases are not normally exposed to environmental matters and do not receive any kind of standardised training in this field. ${ }^{108}$ In addition, the control aspect of the command-and-control measures is reactive in nature, as it reacts to human activity after harm has occurred, rather than responding to human behaviour to prevent that harm from occurring in the first place. ${ }^{109}$

Command-and-control measures in the context of regulating the meat industry, because they do not serve to reduce meat consumption, can be criticised as falling short of adequate 'reasonable measures' aimed at the protection of the environment and securing ecologically sustainable development whilst promoting only justifiable social and economic development. This is the case, as the command-and-control measures seek to mitigate some of the harms caused by meat production, but do not serve to reduce meat consumption (the driving force behind meat production). ${ }^{110}$ Furthermore, these measures allow for environmentally harmful activity to take place (within set thresholds) and in circumstances where even illegal environmentally harmful activity (possibly operating outside of the set threshold) can become legal after the fact in terms of section $24 \mathrm{G}$ of

\footnotetext{
103 Kidd "Criminal Measures" 242.

104 Kidd Environmental Law 270-272.

105 Kidd "Criminal Measures" 243.

106 Fourie 2009 SAJELP 1.

107 Fourie 2009 SAJELP 1.

108 Craigie, Snijman and Fourie "Dissecting Environmental Compliance" 99.

109 Krishnamoorthy Date Unknown https://www.academia.edu/901450/ENVIRON MENTAL_GOVERNANCE-SHIFT_FROM_COMMAND_AND_CONTROL_ MECHANISM_TO_MARKET_DRIVENESTTRATEGIES.

110 Junquera and Del Brio 2016 Sustainability 1-2.
} 
NEMA. ${ }^{111}$ Thus, we argue that command-and-control measures are insufficient to give full effect to the environmental right in the context of the regulation of the meat industry. The command-and-control measures in place do not in our view secure ecological sustainability. Their focus is on sustaining economic growth in the meat industry, with limited regard to the destructive socio-ecological consequences thereof. Moreover, command and control measures alone fail to take into account the Earth's ecological limits and the impacts of exceeding those limits.

\section{The hope of a meat tax}

Taxation can be a tool to "manage behavioural choices made by large numbers of people". ${ }^{112} \mathrm{~A}$ tax, including an environmentally related tax, is a market-based mechanism to regulate human activity and/or human behaviour. ${ }^{113}$ Market-based mechanisms are: ${ }^{114}$

regulations that encourage behaviour through market signals rather than through explicit directives regarding control levels or methods.

This in turn encourages "firms (and/or individuals) to undertake control efforts that both are in those firms'" (or individuals') interests and that collectively meet policy. ${ }^{115}$ This section develops the idea of an environmentally related tax to improve the regulation of the meat industry in the form of a meat tax. We argue that the proposed meat tax could influence human behaviour by reducing meat consumption with the aim of mitigating some of the environmental harms caused by meat production.

\subsection{What is the proposed meat tax?}

Environmentally related taxes, including on greenhouse gas emissions, are a recognised concept globally. ${ }^{116}$ An environmentally related tax is defined as a tax which incorporates the external cost of production or consumption activities, such as the impacts of emissions, in order to address environmental externalities. ${ }^{117}$ The nature and extent of environmentally

111 This argument has been advanced in the above with regard to $S$ 24G of NEMA.

112 Lorenzi 2004 Social Science and Public Policy 59; Carruthers 2016 Fordham L Rev 2566.

113 Miller and Vela 2013 https://www.cbd.int/financial/mainstream/idb-tax.pdf 1.

114 Stavins Market-based Environmental Policies 1.

115 Stavins Market-based Environmental Policies 1.

116 OECD $2006 \mathrm{https}$ ://read.oecd-ilibrary.org/environment/the-political-economy-ofenvironmentally-related-taxes_9789264025530-en\#.

117 Brauer et al Use of Market Incentives to Preserve Biodiversity 23, an externality is used to define situations where the activities "of one (or more than one) economic 
related taxes is dependent on the scope of the externalities. ${ }^{118}$ Our proposed meat tax would be a tax on the greenhouse gas emissions associated with meat products. ${ }^{119}$ The meat tax would thus arise from the imposition of environmentally related taxes by the state.

Furthermore, we would propose that the meat tax be a "consumption tax". A "consumption tax" is defined as a "levy on expenditure relating to the consumption of goods and services". ${ }^{120}$ The proposed meat tax would differ from other types of consumption taxes, such as value-added tax, since it would take into account the negative externalities stemming from the meat production process (as will be discussed in 4.2.2 below). ${ }^{121}$ We propose that the taxed meat products should be poultry, pork, beef and mutton produced in factory farms (as opposed to seafood), as scientific evidence suggests that these products possess the greatest global warming potential by virtue of the socio-ecological impacts discussed above, and are the meat products in greatest demand in South Africa. ${ }^{122}$ Private consumers (largely unknowingly) indirectly contribute to the greenhouse gas emissions emanating from the human activities of particular entities along the meat production chain, as private consumers encourage the continuation of such activities through the purchase of meat produced by those entities. ${ }^{123}$ Thus, it is arguable that the meat consumption of private consumers should be taxed in order to raise awareness amongst private consumers of the

agent(s) have consequences on the economic well-being of other agents, without any kind of exchange or transaction occurring between them."

118 Moolla, McNamara and Nicholis 2014 https://www.nbi.org.za/wpcontent/uploads/2016/06/NBI-Connecting-IPCC-Guidelines-with-Corporate-

Standard-April-2015-final-report.pdf 2-3.

119 Bahr 2015 TEL 153, 155.

120 OECD "Fundamental Principle of Taxation" 32.

121 Centemeri 2009 e-cadernos CES 40; Briggs et al 2016 BMC Public Health 11.

122 In Manning, Reisinger and Bodeker Global Warming Potentials 13, the global warming potential is a climatic metric, which is used to: "compare radiative forcing [the difference of sunlight absorbed by the Earth and energy radiated back to space], the key driver for climate change, over a prescribed time period following pulse emissions of different greenhouse gas emissions." In Van Wyngaard, Meeske and Erasmus 2017 Elsenburg Journal 51, global warming potential considers the following: "concentration [of greenhouse gases] in the atmosphere; how long [greenhouse gases] stays in the atmosphere (lifetime); ability to absorb energy (radiative forcing capacity)."

123 In Kotler and Armstrong "Consumer and Industrial Marketing" 35 "private consumers" are "private individuals who purchase goods and services for personal consumption". This sentence illustrates the compatibility of a consumption tax, in the context of this article, and Scope 3 emissions. This is the case, as Scope 3 emissions focus on indirect emissions and the premise of the proposed meat tax is for private consumers to be taxed on the consumption of meat products in the light of the indirect emissions emanating from along the meat production chain. 
damaging effects of meat production on ecology and human well-being. ${ }^{124}$ A consumption tax approach to regulating the meat industry is supported elsewhere in the world, including in Denmark and Sweden. ${ }^{125}$ The Swedish Ministry of Agriculture argued for a European tax on meat, as price-based approaches are the most effective in changing consumption patterns. ${ }^{126}$ The South African government has been willing to adopt priced-based approaches to influence consumer behaviour in the context of the implementation of excise taxes on alcoholic beverages and tobacco (known as "sin taxes"). These taxes were intended to raise the awareness (among private consumers) of the link between the consumption of alcohol and tobacco and non-communicable chronic diseases such as liver and lung cancer, respectively. ${ }^{127}$

\subsection{The proposed meat tax in a South African legal setting}

In order to understand the potential place of a meat tax in a South African legal setting, we compare and contrast our proposed meat tax with another environmentally related tax, the carbon tax recently introduced by the Carbon Tax Act. We illustrate that a meat tax would be distinguishable from the carbon tax in a number of key ways, and that a meat tax could be introduced as a sin tax under the Customs and Excise Act. ${ }^{128}$ We also engage with some of the arguments against the introduction of such a tax.

\subsubsection{The Carbon Tax}

In terms of section 1 of the Carbon Tax Act, the "carbon tax" is defined as a "tax on the carbon dioxide equivalent of greenhouse gas emissions". Globally, emissions are divided into three broad categories. ${ }^{129}$ Scope 1 emissions are those from sources that are directly controlled or owned by the relevant entity, such as fuel combustion and the use of a company car. ${ }^{130}$ Scope 2 emissions are those that occur as a result of the "generation of electricity, heating and cooling, or steam that is generated off site" but is

\footnotetext{
124 WWF Climate Change on Your Plate 20, 25.

125 FAIRR 2017 https://cdn.fairr.org/2019/01/09120314/meat-tax-probable_final.docx.

126 Masselus Tax on Meat 9.

127 Stacey et al 2017 BMJ Global Health 1-2. According to WHO 2018 https://www.who.int/news-room/fact-sheets/detail/noncommunicable-diseases, "non-communicable disease" (also known as chronic diseases) are the result "of a combination of genetic, physiological, environmental and behavioural factors".

128 Customs and Excise Act 91 of 1964.

129 See for example, United States Environmental Protection Agency Date Unknown https://www.epa.gov/greeningepa/greenhouse-gases-epa.

130 Goitom 2015 http://www.loc.gov/law/foreign-news/article/south-africa-carbon-taxlegislation-proposed/.
} 
purchased by the respective entity. ${ }^{131}$ Scope 3 emissions are indirect emissions that do not form part of Scope 2 emissions and emanate from sources that are not owned or controlled by an entity but are directly related to the activities of that entity. ${ }^{132}$

The carbon tax is conveyed in section 6 of the Carbon Tax Act as a levy that considers allowances, emissions offsets, the tax rate, and the tax period in which the tax will be levied. The carbon tax is further levied on Scope 1 emissions (though the Carbon Tax Act does not explicitly mention the Scope 1 categorisation). ${ }^{133}$ Therefore, the South African carbon tax currently targets producers such as manufacturers, and industrial consumers rather than private consumers. ${ }^{134}$

In terms of the basic formulation for taxation, the carbon tax can be defined as the tax base (the energy source subject to the tax) multiplied by the tax rate (a certain sum of money per ton of carbon dioxide emitted), which provides us with the tax revenue. ${ }^{135}$ The carbon tax is directed towards taxpayers who conduct an ${ }^{136}$

activity as set out in Annexure 1 to the Notices issued by the Minister responsible for environmental affairs in respect of the declaration of greenhouse gases as priority pollutants under section 29(1) read with section 57(1) of [NEMAQA].

Thus, polluters will be held liable for their fossil fuel combustion emissions, certain industrial processes, product use emissions, and fugitive

131 Goitom 2015 http://www.loc.gov/law/foreign-news/article/south-africa-carbon-taxlegislation-proposed/.

132 Goitom $2015 \mathrm{http} / /$ www.loc.gov/law/foreign-news/article/south-africa-carbon-taxlegislation-proposed/.

133 Section 4 of the Carbon Tax Act 15 of 2019 (the Carbon Tax Act); Goitom 2015 http://www.loc.gov/law/foreign-news/article/south-africa-carbon-tax-legislation-

proposed/; GRAIN and IATP 2018 https://www.grain.org/article/entries/5976emissions-impossible-how-big-meat-and-dairy-are-heating-up-the-planet.

134 Section 4 of the Carbon Tax Act provides that the carbon tax must be levied on a taxpayer with regard to greenhouse gas emissions resulting from "fuel combustion and industrial processes, and fugitive emissions". In terms of $s 1$ of the Carbon Tax Act, an "industrial process" is defined as "a manufacturing process that chemically or physically transforms materials", and "fugitive emissions" are defined as "emissions that are released into the atmosphere by any other means than through an intentional release through stack or vent including extraction, processing, delivery and burning of for energy production of fossil fuels, including leaks from industrial plants and pipelines." Therefore, the carbon tax is levied on producers such as manufacturers, and industrial consumers; in Kotler and Armstrong "Consumer and Industrial Marketing" 35, "industrial consumers" are "customers who purchase in order to make or sell their own products or services."

136 Section 3(b) of the Carbon Tax Act. 
emissions. ${ }^{137}$ However, emissions released from the human activities of "Agricultural and Other Land Use and waste sectors" are exempt from the carbon tax due to measurement difficulties. ${ }^{138}$

\subsubsection{Legislative outlook}

Unlike our proposed meat tax (discussed below), the carbon tax is a "production tax". In the context of an environmentally related tax, a "production tax" is a tax according to the level of emission emitted by each producer individually (this corresponds with the definition of Scope 1 emissions). ${ }^{139}$ The carbon tax thus has a potential indirect influence on the human behaviour of private consumers, through directly influencing producers. ${ }^{140}$ This feature of the carbon tax means that there is no guarantee that private consumers will become aware of the link between environmental harm and the human activities resulting in greenhouse gas emissions, as private consumers are only indirectly affected by the carbon tax. The proposed meat tax, as a consumption tax, could be a more effective way of ensuring that private consumers become aware of such a link, as they would be directly affected. ${ }^{141}$

The carbon tax further disregards the majority of greenhouse gas emissions emanating from the meat production chain, as the activities of "Agricultural and Other Land Use and waste sectors" are exempt from the Carbon Tax

137 Section 1 of the Carbon Tax Act.

138 National Treasury 2018 http://www.treasury.gov.za/public\%20comments/ CarbonTaxBill2019/Explanatory\%20Memorandum\%20to\%20the\%202018\%20Car bon\%20Tax\%20Bill\%20-\%2020\%20Nov\%202018.pdf 9. In Government of the RSA 2019 https://www.gov.za/speeches/publication-2019-carbon-tax-act-26-may-20190000 , the carbon tax will be progressively implemented through two phases. The first phase is from 1 June 2019 to 31 December 2022, and the second phase will be from 2023 to 2030. The emissions released from the human activities of the "Agricultural and Other Land Use and waste sectors" will be exempt only in the first phase.

139 Masselus Tax on Meat 21

140 National Treasury 2018 http://www.treasury.gov.za/public\%20comments/ CarbonTaxBill2019/Explanatory\%20Memorandum\%20to\%20the\%202018\%20Car bon\%20Tax\%20Bill\%20-\%2020\%20Nov\%202018.pdf 9; Government of the RSA 2019 https://www.gov.za/speeches/publication-2019-carbon-tax-act-26-may-20190000; Fakoya 2014 Environmental Economics 94.

141 In Masselus Tax on Meat 21-22, the following arguments are provided in support of a consumption tax on meat consumption: "the monitoring costs of greenhouse gas emissions are high for the meat sector. Measuring these emissions would require regular monitoring, which is very expensive; the options to reduce greenhouse gas emissions are limited; the possibilities to substitute meat are numerous. This would lead consumers to adapt their behaviour in a cost-effective way; and to avoid emission leakage. Assuming that the [production] tax is not implemented worldwide, the cost disadvantage that producers in the country or region of the emission tax would obtain, will simply lead to an increase in the import of meat products." 
Act. ${ }^{142}$ Therefore, the carbon tax does not cater for the greenhouse gas emissions resulting from the meat production sector, as Scope 3 emissions and the majority of the greenhouse gas arising from the human activity of meat production do not form part of the carbon tax. ${ }^{143}$ The proposed meat tax would focus on Scope 3 emissions, as they form the bulk of greenhouse gas emissions from a "given company or food product" in the meat production sector. ${ }^{144}$ This is the case as Scope 3 emissions take into consideration: ${ }^{145}$

on-farm emissions from livestock, manure, farm machinery fuel, livestock feed production, production of the inputs needed to produce that feed, land-use changes triggered by the expansion of livestock grazing and feed production, and other sources.

Due to the limited and producer-focussed nature of the carbon tax imposed by the Carbon Tax Act, we believe that a proposed meat tax should be implemented through a separate legislative instrument, rather than form part of the existing Carbon Tax Act. We further suggest that the proposed meat tax should follow a similar construction to that of sin taxes. Sin taxes are implemented through the Customs and Excise Act and levy a tax on particular products deemed to be harmful to society, such as alcoholic beverages and tobacco. ${ }^{146}$ The proposed meat tax could be similarly implemented through the Customs and Excise Act and levy a tax on particular meat products linked to the Scope 3 emissions arising therefrom. In addition, the proposed meat tax could be executed through its own regulations stemming from the Customs and Excise Act, which would address the quirks and key components of the proposed meat tax. The amount levied on each meat product could be calculated in terms of the

142 National Treasury 2018 http://www.treasury.gov.za/public\%20comments/ CarbonTaxBill2019/Explanatory\%20Memorandum\%20to\%20the\%202018\%20Car bon\%20Tax\%20Bill\%20-\%2020\%20Nov\%202018.pdf 9; Government of the RSA 2019 https://www.gov.za/speeches/publication-2019-carbon-tax-act-26-may-20190000 .

143 National Treasury 2018 http://www.treasury.gov.za/public\%20comments/Carbon TaxBill2019/Explanatory\%20Memorandum\%20to\%20the\%202018\%20Carbon\%20 Tax\%20Bill\%20-\%2020\%20Nov\%202018.pdf 9; Government of the RSA 2019 https://www.gov.za/speeches/publication-2019-carbon-tax-act-26-may-2019-0000; Goitom 2015 http://www.loc.gov/law/foreign-news/article/south-africa-carbon-taxlegislation-proposed/; GRAIN and IATP 2018 https://www.grain.org/ article/entries/5976-emissions-impossible-how-big-meat-and-dairy-are-heating-upthe-planet 5 .

144 GRAIN and IATP 2018 https://www.grain.org/article/entries/5976-emissionsimpossible-how-big-meat-and-dairy-are-heating-up-the-planet 5.

145 GRAIN and IATP 2018 https://www.grain.org/article/entries/5976-emissionsimpossible-how-big-meat-and-dairy-are-heating-up-the-planet 5.

146 Kagan 2020 https://www.investopedia.com/terms/s/sin_tax.asp. 
global warming potential and the climate change impacts of each meat product. $^{147}$

\subsubsection{Objections to the meat tax}

It might be argued that privileged consumers who can afford to pay more for meat products, once taxed, would be unmoved by a meat tax, and that their behaviour would not change. However, research by the Thai government indicates that "smoking prevalence among men declined from 44\% in 2003 to $39 \%$ in 2006", primarily due to taxation. ${ }^{148}$ A further study based on 15 years of recent data illustrated that "a $\$ 0.25$ increase in state excise tax is associated with a $0.6 \%$ decrease in population smoking prevalence." 149 In addition, the implementation of the excise tax on alcoholic beverages serves as an example of the ability of a consumption tax to influence the behaviour of private consumers. The consumption of alcoholic beverages has decreased due to the increase in prices (a consequence of excise tax), and producers have reacted to the decrease in demand by producing more nonalcoholic beverages. ${ }^{150}$

Similarly, the proposed meat tax could influence producers to seek more sustainable means of producing meat or producing plant-based meatalternatives in order to better cater for the shift in demand. ${ }^{151}$ Producers may also be indirectly encouraged to create emission-reducing technology (reducing their socio-ecological impacts), rather than the cost-reducing technology promoted by command-and-control measures. ${ }^{152}$

Sin taxes demonstrate the ability of taxes to influence consumer behaviour, even if not to change it entirely. ${ }^{153}$ In any event, even if a tax does not cause

147 One of the reasons why the carbon tax does not consider the greenhouse gases emitted from the agricultural sector is the difficulty of measurement (as the monitoring costs are too high and the agricultural activities resulting in greenhouse gas emission are extensive). However, in Dahlberg French Meat Tax? 4-5 the author argues that "a differentiated consumption tax based on [greenhouse gas] emission intensity per food unit is an effective policy to reduce [greenhouse gas] emission." This is the case, argued in Masselus Tax on Meat 9, as it is easier to calculate the levied amount based on the global warming potential of each meat product than it is to monitor the greenhouse gas emission of the respective meat products produced by each factory farm.

148 White and Ross 2015 Health Economics 131.

149 Sharbaugh et al 2018 PLoS ONE 9.

150 Stacey et al 2017 BMJ Global Health; Wills 2019 https://m.food24.com/Drinks/Beer/the-rise-of-non-alcoholic-beers-and-why-theyregoing-mainstream-20190625; Bird and Wallace Taxing Alcohol in Africa 26.

151 Masselus Tax on Meat 9.

152 Harrington 2007 Resources for the Future 16.

153 Olivola and Sussman "Taxes and Consumer Behaviour" 568-569. 
a drastic shift in consumer behaviour in the short term, it can at least, in combination with other regulatory measures, start a conversation about the socio-ecological impacts of meat production and consumption. Taxing consumers because of the harms caused by meat production and consumption could help to bring these harms to the fore.

A social justice objection to a meat tax could be that impoverished South Africans would be worst affected by the meat tax because the cost of their food would increase and they would no longer be able to afford meat, which is considered a vital source of protein. ${ }^{154}$ Our response to this objection is that measures must be put in place to ensure that the impacts of a meat tax do not adversely impact upon the poor, and to ensure a sustainable and equitable transition away from excessive and environmentally harmful meat production and consumption. ${ }^{155}$ For instance, we propose that meat produced by communal and subsistence farmers not be taxed. This is because, in order to fall under the scope of a factory farm, to which our proposed meat tax would apply, an "intensive animal feeding system" needs to be in operation on that particular farm, which would generally be an established commercial farm, due to the high costs and expensive machinery used to ensure the optimal usage of such a system. ${ }^{156}$ In contrast, the farming practices of communal/subsistence farmers, microscale farmers, small-scale farmers, and emerging farmers have relatively little impact on the environment. ${ }^{157}$ Their activities are ironically characterised, from a neo-liberal capitalist perspective, as inferior to the environmentally harmful farming practices of factory farms, because they supposedly involve: 158

simple, outdated technologies, [with] low returns, high seasonal labour fluctuations and women playing a vital role in production.

Accordingly, meat produced by subsistence/communal farmers, microscale farmers, small-scale farmers, and emerging farmers (participating in the meat production industry) could fall outside of the scope of the proposed

\footnotetext{
154 Chadd, Davies and Koivisto "Practical Production of Protein for Food Animals" 84.

155 See Vinnari and Vinnari 2014 J Agric Environ Ethics 375-391.

156 Section 1(b) of the Health Act, Grobler Regulating the Environmental Impacts of Factory Farming 2.

157 Erasmus and Hoffman 2017 Animal Frontiers 72 demonstrate that rural communities have "limited access to meat" and thus meat is consumed for perceived human survival, not for the purposes of mere indulgence.

158 Department of Agriculture, Forestry and Fisheries 2012 https://www.nda.agric.za/ doaDev/sideMenu/cooperativeandenterprisedevelopment/docs/FRAMEWORK\%200F\%20SMALL\%20FARMERS\%20(2).pdf 1 in Tihanyi and Robinson "Setting the Scene" 3. We refer to Figure 1, which shows the varying kinds of farmers in terms of their development stage.
} 
meat tax, as it does not originate in a factory farm and would thus have far fewer impacts on the environment than meat produced on factory farms. ${ }^{159}$ There are approximately 3 million communal farmers, who account for $40 \%$ of the total cattle available in South Africa. ${ }^{160}$ Most meat products purchased in rural communities are from the "informal market" (which is dominated by communal farmers, micro-scale farmers, small-scale farmers, and emerging farmers). ${ }^{161}$ Therefore, if the application of the meat tax were limited to factory farms, the diets of rural communities would be largely unaffected, as most meat products purchased in rural communities are not from factory farms and thus are produced in less environmentally harmful settings. Another way of ensuring an equitable and sustainable transition from excessive and environmentally harmful meat production and consumption would be to introduce subsidies for plant-based alternatives to meat products to ensure that all people are able to enjoy an affordable, balanced diet. ${ }^{162}$

\section{Conclusion}

This article has argued that the regulation of the human behaviour of meat consumption through the enactment of a proposed meat tax could mitigate the socio-ecological harms caused by the human activity of meat production. In order to prove this, in Section 2 we examined some of the links between socio-ecological harm and the human activity of meat production. We further argued that the human activity of meat production (and consequently its harms) is driven by the human behaviour of meat consumption. In Section 3 we set out a number of the key command-andcontrol measures that are in place to regulate the harms caused by meat production. However, due to the shortcomings of the command-and-control measures, we argued that they are not sufficient to fulfil the environmental right, and fail to secure ecologically sustainable development. In particular, the command-and-control method of regulating the harms caused by meat production does not regulate consumption, the primary reason for meat production, and consequently facilitates its existence. ${ }^{163}$ Further, the permit system in place merely manages environmental degradation by setting thresholds, thus legally permitting an environmentally destructive activity to take place within the boundaries of the set thresholds. ${ }^{164}$ In Section 4,

\footnotetext{
159 Tihanyi and Robinson "Setting the Scene" 3.

160 Sotsha et al 2018 OIDA IJSD 73.

161 Erasmus and Hoffman 2017 Animal Frontiers 72.

162 Vinnari and Vinnari 2014 J Agric Environ Ethics 385.

163 Salzman 2013 Duke Envtl L \& Pol'y F 365.

164 Wilson 2005 Fordham Envtl L Rev 234-235.
} 
through our analysis of the recently introduced carbon tax, we offered a theoretical understanding of the proposed meat tax and further provided guidelines as to how the proposed meat tax could be introduced in South Africa. We suggested that the proposed meat tax be a consumption tax in order that it might induce consumers to become more conscious of the links amongst meat consumption, socio-ecological harm and meat production. ${ }^{165}$ We further suggested that the proposed meat tax could be implemented through regulations (which would address the unique features of the proposed meat tax) stemming from the Customs and Excise Act.

We reiterate that the proposed meat tax envisages regulatory reform by the South African government in response to climate change and other socioecological issues, but is by no means to be viewed as a panacea for the problematic human behaviour and human activities related to and arising from the meat industry. A meat tax could be introduced alongside various policy and other measures such as subsidies and marketing and educational campaigns. ${ }^{166}$ Nonetheless, we maintain that the proposed meat tax offers an innovative means to regulate meat consumption in South Africa because it would be a new tool in response to a modern issue. ${ }^{167}$ The proposed tax seeks to respond to the socio-ecological harms arising from meat production that are compounding the global climate crisis. Among other things, the proposed tax seeks to influence human behaviour and the psychological patterns giving rise thereto by facilitating an increased consciousness of the harms arising from the human activity of meat production. We realise that the introduction of a meat tax would among other reactions face severe cultural and political resistance. Nonetheless, if we are serious about responding to the climate crisis and its dire socioecological consequences, we need to be innovative and imaginative in our regulatory responses, as a business-as-usual approach will have significant implications for the destruction of the Earth and all of its systems, and thus for human survival.

Masselus Tax on Meat 8-9.

Vinnari and Vinnari $2014 \mathrm{~J}$ Agric Environ Ethics 383-385.

In OECD 1996 https://www.oecd.org/sti/inno/2102514.pdf 7 the authors state that "[r]egulation directly affects the innovative process, while innovation and technical change have significant impacts on regulation." 


\section{Bibliography}

\section{Literature}

Anomaly 2015 Public Health Ethics

Anomaly J "What's Wrong with Factory Farming?" 2015 Public Health Ethics 246-254

Ashukem 2017 LEAD Journal

Ashukem JN "Setting the Scene for Climate Change Litigation in South Africa: Earthlife Africa Johannesburg v Minister of Environmental Affairs and Others [2017] ZAGPPHC 58 (2017) 65662/16" 2017 LEAD Journal 37-43

Bahr 2015 TEL

Bahr CC "Greenhouse Gas Taxes on Meat Products: A Legal Perspective" 2015 TEL 153-179

Bailey, Froggatt and Wellesley Livestock

Bailey R, Froggatt A and Wellesley L Livestock - Climate Change's Forgotten Sector: Global Public Opinion on Meat and Dairy Consumption (Research Paper) (Chatham House London 2014)

Bilchitz 2012 SAPL

Bilchitz D "When is Animal Suffering Necessary?" 2012 SAPL 1-29

Bird and Wallace Taxing Alcohol in Africa

Bird RM and Wallace S Taxing Alcohol in Africa: Reflections from International Experience (ITP Paper 0304) (International Tax Program Toronto 2003)

Bosselmann "Ever-increasing Importance of Ecological Integrity"

Bosselmann K "The Ever-increasing Importance of Ecological Integrity in International and National Law" in Westra L et al (eds) Ecological Integrity, Law and Governance (Routledge New York 2018) 225-233

Botai, Botai and Adeola 2018 S Afr J Sci

Botai CM, Botai JO and Adeola AM "Spatial Distribution of Temporal Precipitation Contrasts in South Africa" 2018 S Afr J Sci 70-78

Brauer et al Use of Market Incentives to Preserve Biodiversity Brauer I et al The Use of Market Incentives to Preserve Biodiversity: Final Report (Ecologic Berlin 2006) 
Briassoulis 2019 Land

Briassoulis $\mathrm{H}$ "Combating Land Degradation and Desertification: The Landuse Planning Quandary" 2019 Land 1-26

Briggs et al 2016 BMC Public Health

Briggs ADM et al "Simulating the Impact on Health of Internalising the Cost of Carbon in Food Prices Combined with a Tax on Sugar-sweetened Beverages" 2018 BMC Public Health 1-14

Carruthers 2016 Fordham L Rev

Carruthers BG "The Semantics of Sin Tax: Politics, Morality, and Fiscal Imposition" 2016 Fordham L Rev 2565-2582

Centemeri 2009 e-cadernos CES

Centemeri L "Environmental Damage as Negative Externality: Uncertainty, Moral Complexity and the Limits of the Market" 2009 e-cadernos CES 2140

Chadd, Davies and Koivisto "Practical Production of Protein for Food Animals"

Chadd SA, Davies PW and Koivisto JM "Practical Production of Protein for Food Animals" in FAO Protein Sources for the Animal Feed Industry (FAO Rome 2004) 77-123

Chang et al 2018 Hydrol Earth Syst Sci

Chang $S$ et al "Evaluation of Impacts of Future Climate Change and Water Use Scenarios on Regional Hydrology" 2018 Hydrol Earth Syst Sci 47934813

Colvin et al Water

Colvin C et al Water: Facts and Futures - Rethinking South Africa's Water Future (Report) (World Wildlife Fund-South Africa Cape Town 2016)

Craigie, Snijman and Fourie "Dissecting Environmental Compliance" Craigie F, Snijman P and Fourie M "Dissecting Environmental Compliance and Enforcement in South Africa: Legal Perspectives" in Paterson A and Kotzé L (eds) Environmental Compliance and Enforcement in South Africa - Legal Perspectives (Juta Cape Town 2009) ch 3

Craigie, Snijman and Fourie "Environmental Compliance and Enforcement Institutions"

Craigie $F$, Snijman $P$ and Fourie $M$ "Environmental Compliance and Enforcement Institutions" in Paterson A and Kotzé L (eds) Environmental 
Compliance and Enforcement in South Africa - Legal Perspectives (Juta Cape Town 2009) ch 4

Curran and Hollander 2015 Australas J Environ Manag

Curran G and Hollander R "25 Years of Ecologically Sustainable Development in Australia: Paradigm Shift or Business as Usual?" 2015 Australas J Environ Manag 2-6

Dahlberg French Meat Tax

Dahlberg S A French Meat Tax - An Effective Climate Mitigation Policy? (Environmental Economics and Management Master's dissertation Swedish University of Agricultural Sciences 2017)

De Baker and Dagevos $2012 \mathrm{~J}$ Agric Environ Ethics

De Baker $\mathrm{E}$ and Dagevos $\mathrm{H}$ "Reducing Meat Consumption in Today's Consumer Society: Questioning the Citizen-consumer Gap" 2012 J Agric Environ Ethics 877-894

Elazegui 2002 Policy Brief

Elazegui DD "A Law of Nature - The Command-and-control Approach" 2002 Policy Brief 1-2

Erasmus and Hoffman 2017 Animal Frontiers

Erasmus SW and Hoffman LC "What is Meat in South Africa?" 2017 Animal Frontiers 71-75

Fakoya 2014 Environmental Economics

Fakoya MB "Carbon Tax Policy Implications for Economic Growth and Unemployment Rates in South Africa: A Conceptual Thought" 2014 Environmental Economics 93-98

FAO State of Food and Agriculture

Food and Agriculture Organization of the United Nations The State of Food and Agriculture: Livestock in the Balance (Food and Agriculture Organization of the United Nations Rome 2009)

FAO Tackling Climate Change through Livestock

Food and Agriculture Organization of the United Nations Tackling Climate Change through Livestock: A Global Assessment of Emissions and Mitigation Opportunities (Food and Agriculture Organization of the United Nations Rome 2013) 
Feris 2006 PELJ

Feris LA "Compliance Notices - A New Tool in Environmental Enforcement" 2006 PELJ 1-18

Feris 2008 CCR

Feris L "Sustainable Development in Practice: Fuel Retailers Association of Southern Africa $v$ Director-General Environmental Management, Department of Agriculture, Conservation and Environment, Mpumalanga Province" 2008 CCR 235-253

Fourie 2009 SAJELP

Fourie M "How Civil and Administrative Penalties can Change the Face of Environmental Compliance in South Africa" 2009 SAJELP 1-25

Fresán and Sabaté 2019 Advances in Nutrition

Fresán U and Sebaté $J$ "Vegetarian Diets: Planetary Health and its Alignment with Human Health" 2019 Advances in Nutrition S380-S388

Grobler Regulating the Environmental Impacts of Factory Farming Grobler R Regulating the Environmental Impacts of Factory Farming in South Africa: Legal Perspectives (LLM-dissertation North West University 2012)

Grossi et al 2019 Animal Frontiers

Grossi $\mathrm{G}$ et al "Livestock and Climate Change: Impact of Livestock on Climate and Mitigation Strategies" 2019 Animal Frontiers 69-76

Happer and Wellesley 2019 Food Security Happer C and Wellesley L "Meat Consumption, Behaviour and the Media Environment: A Focus Group Analysis across Four Countries" 2019 Food Security 123-139

Harrington 2007 Resources for the Future Harrington W "Economic Incentives Versus Command and Control: What's the Best Approach for Solving Environmental Problem?" 2007 Resources for the Future 13-17

Holdershaw and Gendall "Understanding and Predicting Human Behaviour" Holdershaw $\mathrm{J}$ and Gendall PE "Understanding and Predicting Human Behaviour" Unpublished contribution delivered at the ANZCA08 Power and Place Conference (July 2008 Wellington) 1-15 
Hornby Oxford Advanced Learner's Dictionary

Hornby AS Oxford Advanced Learner's Dictionary of Current English $8^{\text {th }}$ ed (Oxford University Press Oxford 2010)

Hugo Administrative Penalties

Hugo RE Administrative Penalties as a Tool for Resolving South Africa's Environmental Compliance and Enforcement Woes (LLM-dissertation University of Cape Town 2014)

Humby 2018 JEL Humby $\mathrm{T}$ "The Thabametsi Case: Case No 65662/16 Earthlife Africa Johannesburg v Minister of Environmental Affairs" 2018 JEL 145-155

IPCC Climate Change 2014

Intergovernmental Panel on Climate Change Climate Change 2014: Impacts, Adaptation, and Vulnerability: Summaries, Frequently Asked Questions, and Cross-Chapter Boxes: A Working Group II Contribution to the Fifth Assessment Report of the Intergovernmental Panel on Climate Change (Cambridge University Press Cambridge 2015)

IPCC Global Warming of $1.5^{\circ} \mathrm{C}$

Intergovernmental Panel on Climate Change Global Warming of $1.5^{\circ} \mathrm{C}$. An IPCC Special Report on the Impacts of Global Warming of $1.5^{\circ} \mathrm{C}$ above Preindustrial Levels and Related Global Greenhouse Gas Emission Pathways, in the Context of Strengthening the Global Response to the Threat of Climate Change, Sustainable Development, and Efforts to Eradicate Poverty (IPCC Geneva 2018)

Johnson 1999 Wash \& Lee L Rev

Johnson SM "Economics $v$ Equity: Do Market-based Environmental Reforms Exacerbate Environmental Injustice" 1999 Wash \& Lee L Rev111166

Junquera and Del Brio 2016 Sustainability

Junquera B and Del Brio JA "Preventative Command and Control Regulation: A Case Analysis" 2016 Sustainability 1-17

Kaka Corporate Self-regulation

Kaka I Corporate Self-regulation and Environmental Protection (LLMdissertation North West University 2012) 
Khan 2015 Laws

Khan MR "Polluter-pays-principle: The Cardinal Instrument for Addressing Climate Change" 2015 Laws 638-653

Kidd "Criminal Measures"

Kidd M "Criminal Measures" in Paterson A and Kotzé L (eds) Environmental Compliance and Enforcement in South Africa - Legal Perspectives (Juta Cape Town 2009) ch 10

Kidd Environmental Law

Kidd M Environmental Law $2^{\text {nd }}$ ed (Juta Cape Town 2011)

Kohn 2012 SAJELP

Kohn $L$ "The Anomaly that is Section 24G of NEMA: An Impediment to Sustainable Development" 2012 SAJELP 1-28

Kotler and Armstrong "Consumer and Industrial Marketing"

Kotler P and Armstrong G "Consumer and Industrial Marketing" in Kotler P and Armstrong G Principles of Marketing $10^{\text {th }}$ ed (Prentice Hall Upper Saddle River 2004) ch 4

Kotzé 2014 JERL

Kotzé LJ "Rethinking Global Environmental Law and Governance in the Anthropocene" 2014 JERL 121-156

Kurz et al 2015 Wiley Interdiscip Rev Clim Change

Kurz T et al "Habitual Behaviors or Patterns of Practice? Explaining and Changing Repetitive Climate-relevant Actions" 2015 Wiley Interdiscip Rev Clim Change 113-128

Labuschagne, Louw and Ndanga "Consumer-orientated Study of the South African Beef Value Chain"

Labuschagne A, Louw A and Ndanga L "A Consumer-orientated Study of the South African Beef Value Chain" Unpublished contribution delivered at the Joint 3rd African Association of Agricultural Economists (AAAE) and 48th Agricultural Economists Association of South Africa (AEASA) Conference (19-23 September 2010 Cape Town)

Liverani Climate Change and Individual Behavior Liverani A Climate Change and Individual Behavior: Considerations for Policy (World Bank Washington DC 2010) 
Lorenzi 2004 Social Science and Public Policy

Lorenzi P "Sin Taxes" 2004 Social Science and Public Policy 59-65

Manning, Reisinger and Bodeker Global Warming Potentials

Manning M, Reisinger A, and Bodeker G Global Warming Potentials and Alternate Metrics (New Zealand Climate Change Research Institute Wellington 2009)

Masselus Tax on Meat

Masselus L A Tax on Meat as a Climate Policy Measure (Masters of Science dissertation Ghent University 2016)

Meissner, Scholtz and Engelbrecht 2013 S Afr J Anim Sci

Meissner HH, Scholtz MM and Engelbrecht FA "Sustainability of the South African Livestock Sector towards 2050 Part 1: Worth and Impact of the Sector" 2013 S Afr J Anim Sci 282-297

Miller, Amit and Posten "Behavioral Economics"

Miller JE, Amit E and Posten A "Behavioral Economics" in Encyclopedia of Global Bioethics (Springer International Cham 2016) 1-6

Milne "Carbon Taxes in the United States"

Milne JE "Carbon Taxes in the United States: The Context for the Future" in Milne JE (ed) The Reality of Carbon Taxes in the $21^{\text {st }}$ Century (Western Newspaper Publishing Indianapolis 2008) ch 1

Murcott 2015 SALJ

Murcott M "The Role of Environmental Justice in Socio-economic Rights Litigation" 2015 SALJ 875-908

Murcott "Introducing Transformative Constitutionalism"

Murcott M "Introducing Transformative Constitutionalism in South Africa" in Daly E et al (eds) New Frontiers in Environmental Constitutionalism (UNEP Nairobi 2017) 280-294

Njisane and Muchenje 2017 AJAS

Njisane YZ and Muchenje V "Farm to Abattoir Conditions, Animal Factors and their Subsequent Effects on Cattle Behavioural Responses and Beef Quality - A Review" 2017 AJAS 755-764

OECD "Fundamental Principle of Taxation"

Organisation for Economic Co-operation and Development "Fundamental Principle of Taxation" in Organisation for Economic Co-operation and 
Development Addressing the Tax Challenges of the Digital Economy (OECD Paris 2014) 29-49

Olivola and Sussman "Taxes and Consumer Behaviour"

Olivola C and Sussman AB "Taxes and Consumer Behaviour" in Norton MI (eds) The Cambridge Handbook of Consumer Psychology (Cambridge University Press Cambridge 2015) 564-588

Peel and Osofsky 2018 TEL

Peel $\mathrm{J}$ and Osofsky H "A Rights Turn in Climate Change Litigation" 2018 TEL 27-67

Petrovic et al 2015 Procedia Food Science

Petrovic $Z$ et al "Meat Production and Consumption: Environmental Consequences" 2015 Procedia Food Science 235-238

Poore and Nemecek 2019 Science 360

Poore $\mathrm{J}$ and Nemecek $\mathrm{T}$ "Reducing Food's Environmental Impacts through Producers and Consumers" 2019 Science 360 1-6

Puryear, Bruers and Erdös 2017 J Agric Environ Ethics

Puryear S, Bruers $S$ and Erdös $L$ "On a Failed Defense of Factory Farming" 2017 J Agric Environ Ethics 311-323

Salzman 2013 Duke Envtl L \& Pol'y F

Salzman $\mathrm{J}$ "Teaching Policy Instrument Choice in Environmental Law: The Five P's" 2013 Duke Envtl L \& Pol'y F 363-376

Sharbaugh et al 2018 PLOS ONE

Sharbaugh MS et al "Impact of Cigarette Taxes on Smoking Prevalence from 2001-2015: A Report Using the Behavioral and Risk Factor Surveillance Survey" 2018 PLOS ONE 1-10

Sotsha et al 2018 OIDA IJSD

Sotsha $\mathrm{K}$ et al "Factors Influencing Communal Livestock Farmers' Participation into the National Red Meat Development Programme (NRMDP) in South Africa: The Case of the Eastern Cape Province" 2018 OIDA IJSD 73-80

Stacey et al 2017 BMJ Global Health

Stacey $\mathrm{N}$ et al "Simulating the Impact of Excise Taxation for Disease Prevention in Low-income and Middle-income Countries: An Application to South Africa" 2017 BMJ Global Health 1-6 
Statistics South Africa Mid-year Population Estimates

Statistics South Africa Mid-year Population Estimates (Statistics South Africa Pretoria 2018)

Stavins Market-based Environmental Policies

Stavins RN Market-based Environmental Policies: What Can We Learn from U.S. Experience (and Related Research)? (John F Kennedy School of Government, Harvard University Cambridge 2003)

Springmann et al 2018 PLOS ONE

Springmann $\mathrm{M}$ et al "Heath-motivated Taxes on Red and Processed Meat: A Modelling Study on Optimal Tax Levels and Associated Health Impacts" 2018 PLOS ONE 1-16

Summers "Common-law Remedies for Environmental Protection"

Summers M "Common-law Remedies for Environmental Protection" in Paterson A and Kotzé L (eds) Environmental Compliance and Enforcement in South Africa - Legal Perspectives (Juta Cape Town 2009) ch 13

Swim, Clayton and Howard 2011 Am Psychol

Swim JK, Clayton S and Howard GS "Human Behavioural Contributions to Climate Change: Psychological and Contextual Drivers" 2011 Am Psychol 251-264

Tihanyi and Robinson "Setting the Scene"

Tihanyi K and Robinson K "Setting the Scene" in Mabaya E et al (eds) Case Studies of Emerging Farmers and Agribusinesses in South Africa (Sun Press Stellenbosch 2011) ch 1

Tuomisto and Texieira de Mattos 2011 Environ Sci Technol

Tuomisto HL and Teixeira de Mattos MJ "Environmental Impacts of Cultured Meat Production" 2011 Environ Sci Technol 6117-6123

Turner Factory Farming and the Environment

Turner J Factory Farming and the Environment: A Report for Compassion in World Farming Trust (Compassion in World Farming Trust Petersfield 1999)

Van Wyngaard, Meeske and Erasmus 2017 Elsenburg Journal Van Wyngaard J, Meeske R and Erasmus L "Is Carbon Tax a Reality for Dairy Farmers?" 2017 Elsenburg Journal 51-55 
Vandrovcova "Psychology of Meat Consumption"

Vandrovcova T "The Psychology of Meat Consumption" in Sedova I (eds) Handbook of Research on Social Marketing and It's Influence on Animal Origin Food Product Consumption (IGI Global Hershey 2018) 1-16

Vinnari and Vinnari 2014 J Agric Environ Ethics

Vinnari M and Vinnari E "A Framework for Sustainability: The Case of Plantbased Diets" 2014 J Agric Environ Ethics 369-396

Vlek and Steg 2007 JSI

Vlek $C$ and Steg L "Human Behavior and Environmental Sustainability: Problems, Driving Forces, and Research Topics" 2007 JSI 1-19

Vumbhoni Critical Analysis of the Law on Duty of Care to the Environment Vumbhoni C Critical Analysis of the Law on Duty of Care to the Environment in South Africa: Challenges and Prospects (LLM-dissertation University of Limpopo 2017)

Washington et al 2017 Ecological Citizen

Washington $\mathrm{H}$ et al "Why Ecocentrism is the Key Path to Sustainability" 2017 The Ecological Citizen Y-Z

White and Ross 2015 Health Economics

White JS and Ross H "Smokers' Strategic Responses to Sin Taxes: Evidence from Panel Data in Thailand" 2015 Health Economics 127-141

Wilson 2005 Fordham Envtl L Rev

Wilson MW "A Behavioral Critique of Command-and-control Environmental Regulation" 2005 Fordham Envtl L Rev 223-259

Wilson 2019 Forum of Animal Law Studies

Wilson AP "Animal Law in South Africa: 'Until the Lions have their Own Lawyers, the Law will Continue to Protect the Hunter'" 2019 Forum of Animal Law Studies 35-58

Winstanley "Administrative Measures"

Winstanley T "Administrative Measures" in Paterson A and Kotzé L (eds) Environmental Compliance and Enforcement in South Africa - Legal Perspectives (Juta Cape Town 2009) ch 9

WWF Climate Change on Your Plate

World Wildlife Fund Climate Change on Your Plate (World Wildlife Fund Berlin 2012) 
Zhang 2013 CJPRE

Zhang B "Market-based Solutions: An Appropriate Approach to Resolve Environmental Problems" 2013 CJPRE 87-91

\section{Case law}

Earthlife Africa Johannesburg $v$ Minister of Environmental Affairs [2017] 2 All SA 519 (GP)

Fuel Retailers Association of Southern Africa $v$ Director General: Environmental Management, Department of Agriculture, Conservation and Environment, Mpumalanga Province 20076 SA 4 (CC)

\section{Legislation}

Agricultural Product Standards Act 119 of 1990

Carbon Tax Act 15 of 2019

Conservation of Agricultural Resources Act 43 of 1983

Constitution of the Republic of South Africa, 1996

Customs and Excise Act 91 of 1964

Health Act 63 of 1977

Meat Safety Act 40 of 2000

National Environmental Management Act 107 of 1998

National Environmental Management: Air Quality Act 39 of 2004

National Environmental Management Amendment Act 20 of 2014

National Environmental Management: Waste Act 59 of 2008

National Water Act 36 of 1998

\section{Other government publications}

Environmental Impact Assessment Regulations, 2014 (GN R982 in GG 38282 of 4 December 2014)

Environmental Impact Assessment Regulations Listing Notice 1, 2014 (GN R983 in GG 38282 of 4 December 2014) 
Listed Activities and Associated Minimum Emission Standards Identified in terms of section 21 of the National Environmental Management: Air Quality Act, 2004, 2013 (GN 893 in GG 37054 of 22 November 2013)

National Climate Change Response White Paper, 2011 (GN 757 in GG 34695 of 19 October 2011)

Regulations Regarding the Classification and Marketing of Meat Intended for Sale in the Republic of South Africa, 2006 (GN 863 in GG 29155 of 1 September 2006)

\section{International instruments}

United Nations Framework Convention on Climate Change (1992)

United Nations Convention to Combat Desertification (1994)

Kyoto Protocol to the United Nations Framework Convention on Climate Change (1998)

Paris Agreement (2015)

\section{Internet sources}

Cornelius $2017 \mathrm{http}: / / w w w . r e d m e a t s a . c o . z a / w p-c o n t e n t / u p l o a d s / 2017 / 03 /$ AMT-Beef-Outlook-February-2017.pdf

Cornelius P 2017 AMT Beef Outlook/Review - February 2017 http://www.redmeatsa.co.za/wp-content/uploads/2017/03/AMT-Beef-

Outlook-February-2017.pdf accessed 7 July 2019

Department of Agriculture, Forestry and Fisheries 2012 https://www.nda.agric.za/doaDev/sideMenu/cooperativeandenterprisedeve lopment/docs/FRAMEWORK-\%200F\%20SMALL\%20FARMERS\%20(2) .pdf

Department of Agriculture, Forestry and Fisheries 2012 A Framework for the Development of Smallholder Farmers through Cooperative Development

https://www.nda.agric.za/doaDev/sideMenu/cooperativeandenterprisedeve lopment/docs/FRAMEWORK-\%20OF\%20SMALL\%20FARMERS\%20(2) .pdf accessed 22 January 2021

Department of Agriculture, Forestry and Fisheries 2017 http://webapps.daff.gov.za/AmisAdmin/upload/South\%20African\%20Anim al\%20Feeds\%20Market\%20Analysis\%20Report\%202017.pdf 
Department of Agriculture, Forestry and Fisheries 2017 South African Animal Feeds Market Analysis Report http://webapps.daff.gov.za/Amis Admin/upload/South\%20African\%20Animal\%20Feeds\%20Market\%20Anal ysis\%20Report\%202017.pdf accessed 27 January 2021

Department of Water and Sanitation Date Unknown https://www.dws.gov.za/IO/Docs/CMA/CMA\%20GB\%20Training\%20Manu als/gbtrainingmanualchapter1.pdf

Department of Water and Sanitation Date Unknown Chapter 1: Overview of the South African Water Sector https://www.dws.gov.za//O/Docs/ CMA/CMA\%20GB\%20Training\%20Manuals/gbtrainingmanualchapter1.pd f accessed 15 January 2018

FAO 2016 http://www.fao.org/3/a-i6340e.pdf

Food and Agriculture Organisation of the United Nations 2016 Greenhouse Gas Emissions from Agriculture, Forestry and Other Land Use http://www.fao.org/3/a-i6340e.pdf accessed 22 January 2021

FAO 2017 http://www.fao.org/3/18098EN/i8098en.pdf

Food and Agriculture Organisation of the United Nations 2017 Livestock Solutions for Climate Change http://www.fao.org/3//8098EN/i8098en.pdf accessed 22 January 2021

FAO 2018 http://www.fao.org/3/i8384en//8384EN.pdf

Food and Agriculture Organisation of the United Nations 2018 Shaping the Future of Livestock: Sustainably, Responsibly, Efficiently http://www.fao.org/3/i8384en//8384EN.pdf accessed 22 January 2021

FAIRR 2016 https://cdn.fairr.org/2019/01/09115647/FAIRR_Report_Factory_Farming_ Assessing_Investment_Risks.pdf

Farm Animal Investment Risk and Return 2016 Factory Farming: Assessing Investment Risks https://cdn.fairr.org/2019/01/09115647/FAIRR_Report_ Factory_Farming_Assessing_Investment_Risks.pdf accessed 13 June 2020

FAIRR $2017 \quad$ https://cdn.fairr.org/2019/01/09120314/meat-taxprobable_final.docx

Farm Animal Investment Risk and Return 2017 Climate Tax on Meat Becoming 'Increasingly Probable' https://cdn.fairr.org/ 2019/01/09120314/meat-tax-probable_final.docx accessed 7 July 2019 
Goitom 2015 http://www.loc.gov/law/foreign-news/article/south-africacarbon-tax-legislation-proposed/

Goitom H 2015 South Africa: Carbon-tax Legislation Proposed http://www.loc.gov/law/foreign-news/article/south-africa-carbon-taxlegislation-proposed/ accessed 4 December 2018

Goldblatt 2010 http://awsassets.wwf.org.za/downloads/facts_brochure_ mockup_04_b.pdf

Goldblatt A 2010 Agriculture: Facts and Trends: South Africa http://awsassets.wwf.org.za/downloads/facts_brochure_mockup_04_b.pdf accessed 22 January 2021

Goodland and Anhang 2009 https://awellfedworld.org/wpcontent/uploads/Livestock-Climate-Change-Anhang-Goodland.pdf

Goodland R and Anhang J 2009 Livestock and Climate Change: What if the Key Actors in Climate Change are... Cows, Pigs, and Chickens https://awellfedworld.org/wp-content/uploads/Livestock-Climate-ChangeAnhang-Goodland.pdf accessed 22 January 2021

Gous 2018 https://www.timeslive.co.za/news/south-africa/2018-12-10south-africans-love-meat-but-how-do-we-stack-up-globally/

Gous N 2018 South Africans Love Meat, but How Do We Stack Up Globally? https://www.timeslive.co.za/news/south-africa/2018-12-10-south-africanslove-meat-but-how-do-we-stack-up-globally/ accessed 26 June 2019

Government of the RSA 2019 https://www.gov.za/speeches/publication2019-carbon-tax-act-26-may-2019-0000

Government of the Republic of South Africa 2019 President Cyril Ramaphosa Signs 2019 Carbon Tax Act into Law https://www.gov.za/speeches/publication-2019-carbon-tax-act-26-may2019-0000 accessed 30 June 2019

GRAIN and IATP 2018 https://www.grain.org/article/entries/5976emissions-impossible-how-big-meat-and-dairy-are-heating-up-the-planet GRAIN and the Institute for Agriculture and Trade Policy 2018 Emissions Impossible: How Big Meat and Dairy are Heating Up the Planet https://www.grain.org/article/entries/5976-emissions-impossible-how-bigmeat-and-dairy-are-heating-up-the-planet accessed 22 January 2021 
IPCC 2018 https://www.ipcc.ch/site/assets/uploads/2019/08/2f.-Chapter5_FINAL.pdf

Intergovernmental Panel on Climate Change 2018 Chapter 5: Food Security https://www.ipcc.ch/site/assets/uploads/2019/08/2f.-Chapter-5_FINAL.pdf accessed 14 June 2020

Kagan 2020 https://www.investopedia.com/terms/s/sin_tax.asp Kagan J 2020 Sin Tax https://www.investopedia.com/terms/s/sin_tax.asp accessed 22 January 2021

Khan Academy Date Unknown https://www.khanacademy.org/eceonomicsfinancedomain/microeconomics/consumer-producersurplus/environmentalregulation/a/command-and-control-regulation-cnx Khan Academy Date Unknown Command-and-control Regulation https://www.khanacademy.org/eceonomicsfinancedomain/microeconomics/consumer-producersurplus/environmentalregulation/a/command-and-control-regulation-cnx accessed 30 January 2018

Krishnamoorthy Date Unknown https://www.academia.edu/901450/ ENVIRONMENTAL_GOVERNANCESHIFT_FROM_COMMAND_AND_CONTROL_MECHANISM_TO_MARKE M_DRIVEN_STRATEGIES

Krishnamoorthy B Date Unknown Environmental Governance - Shift from Command and Control Mechanism to Market Driven Strategies https://www.academia.edu/901450/ENVIRONMENTAL_GOVERNANCESHIFT_FROM_COMMAND_AND_CONTROL_MECHANISM_TO_MARKE M_DRIVEN_STRATEGIES accessed 20 June 2019

Miller and Vela 2013 https://www.cbd.int/financial/mainstream/idb-tax.pdf Miller SJ and Vela MA 2013 Are Environmentally Related Taxes Effective? https://www.cbd.int/financial/mainstream/idb-tax.pdf accessed 22 January 2021

Moolla, McNamara and Nicholis 2014 https://www.nbi.org.za/wpcontent/uploads/2016/06/NBI-Connecting-IPCC-Guidelines-with-

Corporate-Standard-April-2015-final-report.pdf

Moolla Z, McNamara A and Nicholis S 2014 Connecting the IPCC Greenhouse Gas Inventory Guidelines with the Corporate Standard (Discussion Draft) https://www.nbi.org.za/wp-content/uploads/2016/06/ NBI-Connecting-IPCC-Guidelines-with-Corporate-Standard-April-2015final-report.pdf accessed 22 January 2021 
National Treasury 2018 http://www.treasury.gov.za/public\%20comments/ CarbonTaxBill2019/Explanatory\%20Memorandum\%20to\%20the\%202018 \%20Carbon\%20Tax\%20Bill\%20-\%2020\%20Nov\%202018.pdf

National Treasury 2018 Explanatory Memorandum on the Carbon Tax Bill, 2018

http://www.treasury.gov.za/public\%20comments/CarbonTaxBill2019/Expla natory\%20Memorandum\%20to\%20the\%202018\%20Carbon\%20Tax\%20B ill\%20-\%2020\%20Nov\%202018.pdf accessed 22 January 2021

OCE 2018 https://www.ipcc.ch/site/assets/uploads/sites/2/2019/03/ ST1.5_final_310119.pdf

Office for Climate Education 2018 IPCC Special Report: Global Warming of $1.5^{\circ} \mathrm{C}$ - Summary for Teachers https://www.ipcc.ch/site/assets/uploads/ sites/2/2019/03/ST1.5_final_310119.pdf accessed 22 January 2021

OECD 1996 https://www.oecd.org/sti/inno/2102514.pdf

Organisation for Economic Co-operation and Development 1996 Regulatory Reform and Innovation https://www.oecd.org/sti/ inno/2102514.pdf accessed 24 July 2019

OECD 2006 https://read.oecd-ilibrary.org/environment/the-politicaleconomy-of-environmentally-related-taxes_9789264025530-en\#

Organisation for Economic Co-operation and Development 2006 The Political Economy of Environmentally Related Taxes https://read.oecdilibrary.org/environment/the-political-economy-of-environmentally-relatedtaxes_9789264025530-en\# accessed 25 June 2019

Ritchie and Roser 2017 https://ourworldindata.org/meat-and-seafoodproduction-consumption

Ritchie H and Roser M 2017 Meat and Dairy Production https://ourworldindata.org/meat-and-seafood-production-consumption accessed 19 May 2019

Sahney Date Unknown http://www.nptel.ac.in/courses/110105029/pdf\% 20sahany/Module-1-1.pdf

Sahney S Date Unknown Module 1: Introduction to the Study of Consumer Behavior

http://www.nptel.ac.in/courses/110105029/pdf\%20sahany/Module-1-1.pdf accessed 30 June 2018 
Stockholm Resilience Centre 2015 https://www.stockholmresilience.org/ research/research-news/2015-02-19-what-is-resilience.html

Stockholm Resilience Centre 2015 What is Resilience? https://www.stockholmresilience.org/research/research-news/2015-02-19what-is-resilience.html accessed 16 May 2019

UN Date Unknown https://www.un.org/en/sections/issues-depth/climatechange/

United Nations Date Unknown Climate Change https://www.un.org/en/sections/issues-depth/climate-change/ accessed 22 January 2021

UN High Commissioner for Human Rights 2019 https://www.ohchr.org/EN/NewsEvents/Pages/DisplayNews.aspx?NewsID $=24735 \&$ Lang $\mid \mathrm{D}=\mathrm{E}$

United Nations Office of the High Commissioner for Human Rights 2019 UN Expert Condemns Failure to Address Impact of Climate Change on Poverty https://www.ohchr.org/EN/NewsEvents/Pages/DisplayNews.aspx?NewsID $=24735 \&$ LangID $=E$ accessed 27 June 2019

United States Department of Agriculture, Foreign Agricultural Service 2015 https://www.fas.usda.gov/data/south-africa-south-african-meat-market United States Department of Agriculture, Foreign Agricultural Service 2015 The South African Meat Market (Global Agricultural Information Network Report) https://www.fas.usda.gov/data/south-africa-south-african-meatmarket accessed 22 January 2021

United States Environmental Protection Agency Date Unknown https://www.epa.gov/greeningepa/greenhouse-gases-epa

United States Environmental Protection Agency Date Unknown Greenhouse Gases at EPA https://www.epa.gov/greeningepa/ greenhouse-gases-epa accessed 8 February 2021

Van Dam 2017 http://edition.cnn.com/2017/05/31/africa/cape-towndrought/index.html

Van Dam D 2017 Cape Town Contends with Worst Drought in Over a Century http://edition.cnn.com/2017/05/31/africa/cape-town-drought/index.html accessed 4 October 2017 
WHO $2018 \quad$ https://www.who.int/news-room/fact-sheets/detail/noncommunicable-diseases

World Health Organisation 2018 Noncommunicable Diseases https://www.who.int/news-room/fact-sheets/detail/noncommunicablediseases accessed 22 January 2021

Wills 2019 https://m.food24.com/Drinks/Beer/the-rise-of-non-alcoholicbeers-and-why-theyre-going-mainstream-20190625

Wills O 2019 The Rise of Non-alcoholic Beers and why They're Going Mainstream https://m.food24.com/Drinks/Beer/the-rise-of-non-alcoholicbeers-and-why-theyre-going-mainstream-20190625 accessed 22 January 2021

Worldwatch Institute $2017 \mathrm{http}: / /$ www. worldwatch.org/node/5443

Worldwatch Institute 2017 Meat Production Continues to Rise http://www.worldwatch.org/node/5443 accessed 8 November 2017

Zimmerman and Cliffs 2001 http://dwardmac.pitzer.edu/Anarchist_ Archives/bookchin/coceol.html

Zimmerman ME and Cliffs E 2001 What is Social Ecology? http://dwardmac.pitzer.edu/Anarchist_Archives/bookchin/coceol.html accessed 6 December 2018

\section{List of Abbreviations}

AJAS

Am Psychol

Australas J Environ Manag

CCR

CJPRE

Duke Envtl L \& Pol'y F

Environ Sci Technol

FAIRR

FAO

Fordham Envtl L Rev

Fordham L Rev

Hydrol Earth Syst Sci

IATP
Asian-Australasian Journal of Animal

Science

American Psychologist

Australasian Journal of Environmental

Management

Constitutional Court Review

Chinese Journal of Population Resources

and Environment

Duke Environmental Law and Policy Forum

Environmental Science and Technology

Farm Animal Investment Risk and Return

Food and Agriculture Organisation of the United Nations

Fordham Environmental Law Review

Fordham Law Review

Hydrology and Earth System Sciences

Institute for Agriculture and Trade Policy 
IPCC

$J$ Agric Environ Ethics

JEL

JERL

LEAD Journal

JSI

NEMA

NEMAQA

NEMWA

NWA

OCE

OECD

OIDA IJSD

PELJ

RSA

$S$ Afr J Anim Sci

$S$ Afr J Sci

SAJELP

SALJ

SAPL

TEL

UN

Wash \& Lee L Rev

WHO

Wiley Interdiscip Rev Clim Change

WWF
Intergovernmental Panel on Climate Change Journal of Agricultural Environmental Ethics Journal of Environmental Law Journal of Energy and Natural Resources Law

Law, Environment and Development Journal Journal of Social Issues

National Environmental Management Act 107 of 1998

National Environmental Management: Air Quality Act 39 of 2004

National Environmental Management:

Waste Act 59 of 2008

National Water Act 36 of 1998

Office for Climate Education

Organisations for Economic Co-operation and Development

OIDA International Journal of Sustainable Development

Potchefstroom Electronic Law Journal

Republic of South Africa

South African Journal of Animal Science

South African Journal of Science

South African Journal of Environmental Law and Policy

South African Law Journal

Southern African Public Law

Transnational Environmental Law

United Nations

Washington and Lee Law Review

World Health Organisation

Wiley Interdisciplinary Reviews - Climate

Change

World Wildlife Fund 